\title{
$\beta$-Nicotinamide Mononucleotide (NMN) Administrated by Intraperitoneal Injection Mediates Protection Against UVB-Induced Skin Damage in Mice
}

\author{
Xianrong Zhou ${ }^{\mathrm{I}-4, *}$ \\ Hang-Hang Du ${ }^{5, *}$ \\ Xingyao Long ${ }^{1-3}$ \\ Yanni Pan ${ }^{1-3}$ \\ Jian $\mathrm{Hu}^{6}$ \\ Jianjun $\mathrm{Yu}^{6}$ \\ Xin Zhao (D) ${ }^{1-3}$ \\ 'Chongqing Collaborative Innovation Center \\ for Functional Food, Chongqing University of \\ Education, Chongqing, People's Republic of \\ China; ${ }^{2}$ Chongqing Engineering Research \\ Center of Functional Food, Chongqing \\ University of Education, Chongqing, People's \\ Republic of China; ${ }^{3}$ Chongqing Engineering \\ Laboratory for Research and Development of \\ Functional Food, Chongqing University of \\ Education, Chongqing, People's Republic of \\ China; ${ }^{4}$ Department of Food and Nutrition, \\ College of Medical and Life Sciences, Silla \\ University, Busan, South Korea; ${ }^{5}$ Department \\ of Plastic Surgery, Chongqing Huamei Plastic \\ Surgery Hospital, Chongqing, People's \\ Republic of China; ${ }^{6}$ R\&D Department, \\ Effepharm (Shanghai) Co., Ltd, Shanghai, \\ People's Republic of China \\ *These authors contributed equally to this \\ work
}

Correspondence: Xin Zhao

Chongqing Collaborative Innovation Center for Functional Food, Chongqing University of Education, Xuefu Main Street 9, Chongqing, 400067, People's Republic of China

Email zhaoxin@cque.edu.cn

Jianjun Yu

R\&D Department, Effepharm (Shanghai)

Co., Ltd, Room 20I, Building 12, No. I,

Wangdong Middle Road, Sijing Town,

Shanghai, 20I60I, People's Republic of

China

Email jianjun.yu@effepharm.com
Objective: Ultraviolet light is an important environmental factor that induces skin oxidation, inflammation, and other diseases. Nicotinamide mononucleotide (NMN) has the effect of antioxidation and improving various physiological processes. This study explores the protective effect of NMN monomers given via intraperitoneal injection on UVB-induced photodamage.

Methods: We used a murine model of UVB-induced photodamage to evaluate the effect of an NMN monomer on photoaging skin by assessing skin and liver tissue sections, serum and skin oxidative stress levels, inflammatory markers, mRNA expression, and protein expression of skin- and liver-related genes. Results: The results showed that NMN treatment blocked UVB-induced photodamage in mice, maintaining normal structure and amount of collagen fibers, normal thickness of epidermis and dermis, reducing the production of mast cells, and maintaining complete organized skin structure. NMN intraperitoneal injection also maintained the normal morphology of the mouse liver after UVB exposure. Meanwhile, NMN intraperitoneal injection was found to increase antioxidant ability and regulate the proinflammatory response of the skin and liver to UVB irradiation by enhancing the activity of antioxidant enzymes, release of anti-inflammatory cytokines, reduction of hydrogen peroxide production $\left(\mathrm{H}_{2} \mathrm{O}_{2}\right)$, and decreased inflammatory cytokines. Furthermore, RTqPCR results indicated that NMN reduced oxidative stress of skin and liver by promoting the activation of the AMP-activated protein kinase (AMPK) signaling pathway and further increasing the expression of downstream antioxidant genes of AMPK. RT-qPCR results also revealed that NMN treatment could downregulate the mRNA expression of interleukin (IL)-6, interleukin (IL)$1 \beta$, and tumor necrosis factor (TNF)- $\alpha$, and upregulate NF-kappa-B inhibitor- $\alpha(\mathrm{I} \kappa \mathrm{B}-\alpha)$ and interleukin (IL)-10 by inhibiting the activation of nuclear factor- $\kappa$ Bp65 (NFkB-p65). Finally,

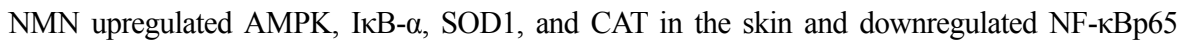
protein expression, which is in line with the RT-qPCR results.

Conclusion: Based on the above results, NMN monomer treatment with intraperitoneal injection also block the photodamage caused by UVB irradiation in mice by regulating the oxidative stress response and inflammatory response.

Keywords: nicotinamide mononucleotide, UVB, antioxidant, NF- $\mathrm{kp} 65$ signaling pathway, AMP-activated protein kinase signaling pathway

\section{Background}

Skin plays an important role in protection, body temperature regulation, sensation, secretion, excretion, and immunity. ${ }^{1}$ With the increase of age or the stimulation of 
external environmental factors, the skin's function will degenerate day by day. UV-irradiation is considered the most significant environmental factor that causes photoaging to the skin. ${ }^{2}$ Ultraviolet radiation is generally divided into longwave UVA $(320 \mathrm{~nm}-400 \mathrm{~nm})$, narrow-band UVB (280nm-320nm), and shortwave UVC (200 nm-280 nm. ${ }^{3}$ Among them, UVC is absorbed and scattered by the ozone layer in the atmosphere because of its short wavelength, so it cannot reach the earth's surface. The wavelength of UVB can only reach the epidermis of the skin, while the longer UVA will penetrate deep into the skin, damage the dermis layer of the skin, and cause skin aging. ${ }^{4}$

Long-term ultraviolet radiation can cause serious damage to the skin, such as cortex redness and dryness, epidermal breakage, muscle relaxation, rough folds, and abnormal local pigment deposition. These changes are the end product the production of a large number of reactive oxygen species (ROS), degradation of collagen fibers, increased inflammation, DNA damage and even skin cancer. ${ }^{5-7}$ Therefore, finding methods to prevent or reduce UV irradiation damage to the skin is an important research focus. Nicotinamide ribonucleotide (NMN) is a biologically active nucleotide that is formed by the reaction of a phosphate group with a riboside containing ribose and nicotinamide. It possesses a large number of beneficial pharmacological activities in several preclinical disease models, including neurodegenerative disease models such as myocardial and cerebral ischemia, Alzheimer's disease, and diabetes. ${ }^{8-11}$ Nicotinamide mononucleotide (NMN) is also an intermediate in the NADK salvage synthesis pathway in mammals, generating NADK under the action of nicotinamide mononucleotide adenylyltransferase (NMNAT) ${ }^{12}$ NADK exists in all cells of the human body, and its normal level is important for maintaining the homeostasis of mitochondria, the metabolism of organisms, the normal functions of organs and tissues, and delaying aging, but the ability of NADK to penetrate the plasma membrane is also less efficiently than that of NMN, study proved that increased NADK levels restored the reproductive function of aged mice by NMN treatment. ${ }^{13}$ A new study described that NMN oral administration could effectively improve age-related mitochondrial oxidative stress and increase brain function of aged mice. ${ }^{14}$ In a different study, NMN combined with exercise greatly enhanced the content of antioxidants and reduced prooxidants in islets and muscle of obese mice. ${ }^{15}$ Because of such results, anti-ageing and longevity properties in mouse models have made NMN highly attractive. However, there are only a few reports on the effect of NMN on UVB-induced skin photoaging. ${ }^{16}$
At present, oral gavage and intraperitoneal injection are two main methods for NMN administration in vivo. ${ }^{17,18}$ A previous study compared the influence of oral gavage and intraperitoneal injection of ethanol on bone metabolism. Their results indicated that intraperitoneal injection significantly reduced body weight and bone measurements of rats, but oral gavage has no obvious effect on the same indicators. ${ }^{19}$ In contrast, research showed that there was no significant difference between gavage and subcutaneous injection of indole-3-acetic acid on leukocytes in rats. ${ }^{20}$ Our previous study found NMN oral administration could block skin damage induced by UVB exposure in mouse skin. ${ }^{21}$ Based on these results, we wondered whether NMN administered via intraperitoneal injection has a similar effect on UVB-induced skin damage, so we carried out the present study.

It is well known that vitamin $\mathrm{C}$ is a strong and effective antioxidant. A previous study indicated that Vitamin $\mathrm{C}$ combined with Quercetin reduced oxidative damage in cadmium-intoxicated rats by increasing oxidative enzymes, such as CAT, GSH, SOD, and others. ${ }^{22}$ Another study found vitamin $\mathrm{C}$ significantly improved UVB-induced skin damage with its antioxidative properties. ${ }^{23}$ Based on these backgrounds, in many antioxidant experiments, vitamin $\mathrm{C}$ is selected as the positive control. $^{24,25}$

In this study, mice with UVB-induced photodamage were used as experimental subjects. The mice were intraperitoneally injected with nicotinamide mononucleotide, and then serum and skin oxidation indexes, inflammation indexes, and mRNA expression levels of related genes in the skin and liver were measured to characterize the extent of photodamage. The present study may provide theoretical knowledge for the prevention or treatment of skin photoaging with NMN.

\section{Methods}

\section{NMN Source}

NMN (CAS number: 1094-61-7) was provided by Effepharm Technology Co., Ltd. (Shanghai, China). NMN's purity was measured by high-performance liquid chromatography (Ultimate 3000; Thermo Fisher Scientific, Inc., Waltham, MA, USA) and was shown to be $>98.5 \%$.

\section{Experimental Animals}

Forty 7-week-old female ICR mice were purchased from Chongqing Byrness Weil biotech Ltd [Chongqing, China, 
SCXK (XIANG) 2018-0003]. The mice were kept under constant temperature and humidity conditions (temperature of $25 \pm 2{ }^{\circ} \mathrm{C}$, relative humidity of $50 \pm 5 \%$ ) and a 12 hours light/dark cycle. Mice consumed standard mice food and drinking water freely. These experiments were approved by the Ethics Committee of Chongqing Collaborative Innovation Center for Functional Food (201906003B), Chongqing, China.

\section{UVB-Induced Skin Oxidative Damage}

After 1 week of adaptation, forty mice were randomly divided into 4 groups, with 10 mice in each group. 10 mice in the same group were housed in the same cage; namely, the control group, UVB group, vitamin C (VC) +UVB group, and nicotinamide mononucleotide (NMN) +UVB group. The entire experimental period was 4 weeks. The specific treatment of each group of mice was as follows (Supplementary Figure 1): (1) control group, mice received an intraperitoneal injection with saline solution every day; (2) UVB group, mice received an intraperitoneal injection with saline solution every day; (3) VC + UVB group, mice were oral administered VC solution at a dose of $300 \mathrm{mg} / \mathrm{kg}$.bw every day; (4) NMN+UVB group, mice received an intraperitoneal injection with NMN aqueous ultrapure solution at a dose of $300 \mathrm{mg} / \mathrm{kg} . \mathrm{bw}$ every day. In addition, from the 3rd week onwards, skin damage was established with a UV radiation device (UV lamp FS40, 290-400 nm; Candela Corp., Santa Ana, CA, USA) in the mice in the UVB, VC, and NMN groups but not in the control group. UVB light was installed at the top of the wooden box, $30 \mathrm{~cm}$ away $\left(320 \mathrm{~nm}, 120 \mathrm{~mJ} / \mathrm{cm}^{2} / \mathrm{sec}\right)$ from the bottom of the box. ${ }^{26,27}$ The specific irradiation method was to clean the litter in the cages of each group of mice, remove the water bottles, and then put all the mice in the cages into the bottom of the wooden box for irradiation. Irradiation was performed for $3 \mathrm{~min}$ every day. ${ }^{28}$ Before UV irradiation, researchers shaved approximately $2 \mathrm{~cm}^{2}$ of hair from the back of the mouse with an electric razor (Head Venture Biotechnology Co., Ltd., Beijing, China). All experiments were approved by Chongqing Functional Food Collaborative Innovation Center. The dose of NMN was set according to a previous study. ${ }^{29}$

\section{Sample Collection}

On the last day of week 4, blood and tissue samples were collected. After the mice were anesthetized with diethyl ether, whole blood was collected from the inferior vena cava, and the serum was collected by centrifugation and stored at $-80{ }^{\circ} \mathrm{C}$ until use. The mice were then sacrificed by spinal removal. ${ }^{30}$ Mice were dissected, and the livers and the hairless skin on the back were removed. Soybean-sized pieces of liver and skin tissue were collected and kept in a $4 \%$ paraformaldehyde solution. The remaining liver and skin tissue samples were stored in the $-80{ }^{\circ} \mathrm{C}$ refrigerator (Thermo Fisher Scientific Co. Ltd., Shanghai, China).

\section{Histomorphological Technique}

The liver was stained with H\&E, and the skin was stained with Masson's trichrome, H\&E, and toluidine blue (TB). ${ }^{31}$ Generally speaking, the liver and skin tissues are first fixed with $10 \%$ formaldehyde, then dehydrated with alcohol, transparent with xylene, and embedded in paraffin. Then, the embedded wax block was cut into 5-8 micron slices with a microtome, and dried at a constant temperature at $45{ }^{\circ} \mathrm{C}$. Thirdly, different dyes are added for dyeing. Among them, H\&E is dyed with hematoxylin and eosin, Masson is dyed with hematoxylin and ponceau acid red liquor, and TB is dyed with toluidine blue. An upright microscope (BX43, Olympus, Tokyo, Japan) was used to observe the pathological morphology of the tissue.

\section{Biochemical Analysis of Oxidative Stress}

Based on the instructions of the kit (Nanjing JianCheng Bioengineering Institute, Nanjing, China), the levels of CAT (cat. no. A007-1-1), AGEs (cat. no. H250-1-1), T-SOD (cat. no. A001-1-2), and $\mathrm{H}_{2} \mathrm{O}_{2}$ (cat. no. A0641-1) in the serum of the mice were measured. Similarly, the levels of T-SOD (cat. no. A001-1-2), CAT (cat. no. A007-1-1), AGEs (cat. no. $\mathrm{H} 250-1-1$ ), $\mathrm{H}_{2} \mathrm{O}_{2}$ (cat. no. A064-1-1), $\mathrm{Na}^{+}-\mathrm{K}^{+}$-ATPase (cat. no. A016-2-2) and NADK (cat. no. A117-1-1) were measured in skin tissues according to the kit (Nanjing JianCheng Bioengineering Institute, Nanjing, China) instructions.

\section{ELISA Assay of Some Inflammatory Cytokines}

The levels of IL-4 (ml063156-J), IL-6 (ml064292), IL-10 (ml037873), TNF- $\alpha$ (ml037211), and IL-1 $\beta$ (ml063132) in serum and skin tissue were measured according to the instructions of the ELISA kit (Shanghai Enzyme-Linked Biotechnology Co., Ltd, Shanghai, China).

\section{RT-qPCR Gene Analysis}

A slight modification based on previous methods, ${ }^{32,33}$ TRIzol reagent was used to extract the total RNA of the 
liver and skin tissues, and then $1 \mu \mathrm{g}$ RNA was reverse transcribed into cDNA with a cDNA kit. Then, $1 \mu \mathrm{L}$ of cDNA, $10 \mu \mathrm{L}$ of TaqMan ${ }^{\mathrm{TM}}$ Multiplex Master Mix, $2 \mu \mathrm{L}$ of $10 \mu \mathrm{M}$ primer, and $7 \mu \mathrm{L}$ of $\mathrm{ddH}_{2} \mathrm{O}$ were mixed well, and amplification and detection were performed with a real-time fluorescence quantitative PCR instrument (Thermo Fisher Scientific, Inc., Waltham, MA, USA).
The amplification conditions were as follows: denaturation for $15 \mathrm{~s}$ at $95{ }^{\circ} \mathrm{C}$, annealing at $55^{\circ} \mathrm{C}$ for $30 \mathrm{~s}$, extension at $72{ }^{\circ} \mathrm{C}$ for $35 \mathrm{~s}$, and a total of 40 cycles. Finally, the formula of $2^{-\Delta \Delta C T}$ was used to calculate the relative expression of each target gene, with $\beta$-actin as the internal reference gene. ${ }^{34}$ The primer sequences used in this experiment are presented in Table 1.

Table I Sequences of the Primers Used for the Mice Liver and Skin Tissues

\begin{tabular}{|c|c|c|}
\hline Gene & Sequences & Gene ID \\
\hline$N F-\kappa B p 65$ & $\begin{array}{l}\text { F:5'- GAGGCACGAGGCTCCTTTTCT -3' } \\
\text { R:5'- GTAGCTGCATGGAGACTCGAACA -3' }\end{array}$ & XM_006531695.3 \\
\hline $\mid \kappa B-\alpha$ & $\begin{array}{l}\text { F:5'-TGAAGGACGAGGAGTACGAGC-3' } \\
\text { R:5'-TGCAGGAACGAGTCTCCGT-3' }\end{array}$ & XM_02II I \\
\hline$T N F-\alpha$ & $\begin{array}{l}\text { F:5'-CAGGCGGTGCCTATGTCTC-3' } \\
\text { R:5'-GCTGCAACAGGGGGTAACAT-3' }\end{array}$ & NM_013693.3 \\
\hline IL-6 & $\begin{array}{l}\text { F:5'-CTGCAAGAGACTTCCATCCAG-3' } \\
\text { R:5'-AGTGGTATAGACAGGTCTGTTGG-3' }\end{array}$ & NM_03II68.2 \\
\hline IL- 10 & $\begin{array}{l}\text { F:5'-CTTACTGACTGGCATGAGGATCA-3' } \\
\text { R:5'-GCAGCTCTAGGAGCATGTGG-3' }\end{array}$ & NM_010548.2 \\
\hline SODI & $\begin{array}{l}\text { F:5'-AACCAGTTGTGTTGTCAGGAC-3' } \\
\text { R:5'-CCACCATGTTTCTTAGAGTGAGG-3' }\end{array}$ & NM_0II434.I \\
\hline SOD2 & $\begin{array}{l}\text { F:5'-CAGACCTGCCTTACGACTATGG-3' } \\
\text { R:5'-CTCGGTGGCGTTGAGATTGTT-3' }\end{array}$ & NM_01367I.3 \\
\hline CAT & $\begin{array}{l}\text { F:5'-GGAGGCGGGAACCCAATAG-3' } \\
\text { R:5'-GTGTGCCATCTCGTCAGTGAA-3' }\end{array}$ & NM_009804.2 \\
\hline GSH & $\begin{array}{l}\text { F:5'-CCACCGTGTATGCCTTCTCC-3' } \\
\text { R:5'-AGAGAGACGCGACATTCTCAAT-3' }\end{array}$ & NM_008I60.6 \\
\hline AMPK & $\begin{array}{l}\text { F:5'-GTCAAAGCCGACCCAATGATA-3' } \\
\text { R:5'-CGTACACGCAAATAATAGGGGTT-3' }\end{array}$ & NM_00I013367.3 \\
\hline$L K B I$ & $\begin{array}{l}\text { F:5'-CTGGACTCCGAGACCTTATGC-3' } \\
\text { R:5'-CAAGCTGGATCACATTCCGAT-3' }\end{array}$ & NM_0II492.5 \\
\hline SIRTI & $\begin{array}{l}\text { F:5'-TGATTGGCACCGATCCTCG-3' } \\
\text { R:5'-CCACAGCGTCATATCATCCAG-3' }\end{array}$ & NM_00II59589.2 \\
\hline mTOR & $\begin{array}{l}\text { F:5'-CAGTTCGCCAGTGGACTGAAG-3' } \\
\text { R:5'-GCTGGTCATAGAAGCGAGTAGAC-3' }\end{array}$ & NM_020009.2 \\
\hline$P G C-I \alpha$ & $\begin{array}{l}\text { F:5'-TATGGAGTGACATAGAGTGTGCT-3' } \\
\text { R:5'-GTCGCTACACCACTTCAATCC-3' }\end{array}$ & NM_008904.2 \\
\hline APPLI & $\begin{array}{l}\text { F:5'-AGCCAGTGACCCTTTATATCTGC-3' } \\
\text { R:5'-AGGTATCCAGCCTTTCGGGTT-3' }\end{array}$ & NM_I45221.2 \\
\hline FOXO & $\begin{array}{l}\text { F:5'-CCCAGGCCGGAGTTTAACC-3' } \\
\text { R:5'-GTTGCTCATAAAGTCGGTGCT-3' }\end{array}$ & NM_019739.3 \\
\hline$\beta$-actin & $\begin{array}{l}\text { F:5'-CATGTACGTTGCTATCCAGGC-3' } \\
\text { R:5'-CTCCTTAATGTCACGCACGAT-3' }\end{array}$ & NC_00007I.7 \\
\hline
\end{tabular}




\section{Western Blot Analysis}

Total protein in liver and skin tissue was extracted with RIPA reagent (Thermo Fisher Scientific, Inc., Waltham, MA, USA), and the concentration of protein was determined with a BCA protein quantification kit (Beijing Solarbio Technology Co., Ltd., Beijing, China). Referring to the previous literature, the Western blot method is mainly used to detect the relative expression of protein lysates. ${ }^{34,35}$ The specific primary antibodies used in this experiment were rabbit anti-mouse AMPK polyclonal antibody (PA5105297; 1:1000), rabbit anti-mouse NFkB-p65 polyclonal antibody (51-0500; 1:200), rabbit anti-mouse IкB- $\alpha$ polyclonal antibody (PA5-17888; 1:1000), rabbit anti-mouse SOD1 polyclonal antibody (PA5-85095; 1:5000) and rabbit anti-mouse CAT polyclonal antibody (PA5-29183; 1:2000) (Thermo Fisher Scientific, Inc., Waltham, MA, USA). The secondary antibody used was Goat anti-Mouse $\operatorname{IgG}(\mathrm{H}+\mathrm{L})$ Cross-Adsorbed Secondary Antibody, HRP (G-21040; $1: 10,000)$. ImageJ software was used to analyze the grey value of the protein bands (National Institutes of Health, USA). Finally, the relative expression of the target genes was calculated using $\beta$-actin as an internal reference. ${ }^{36}$

\section{Statistical Analysis}

SPSS17.0 (IBM Corp., Armonk, NY, USA) statistical software was used to analyze the related oxidative stress
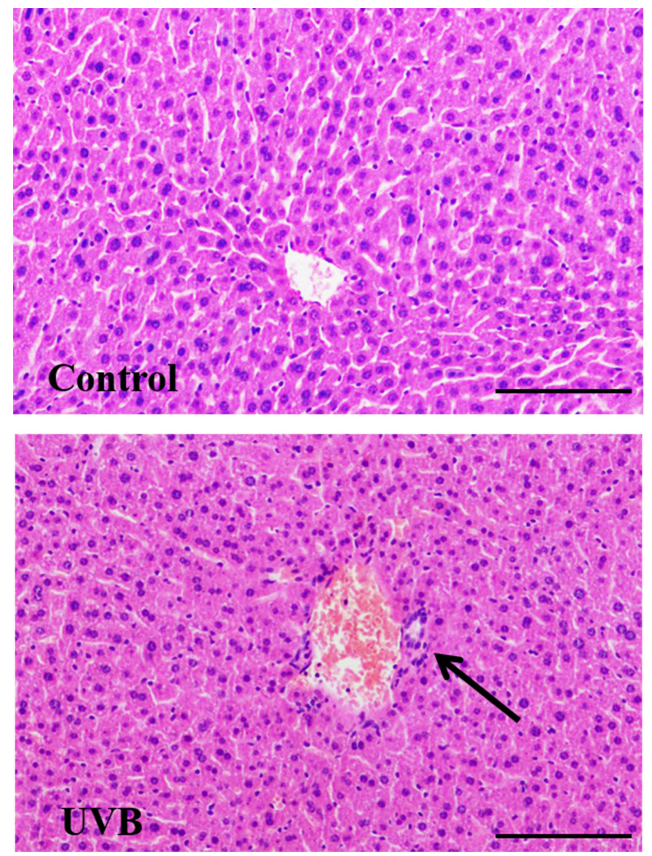

indicators and inflammation indicators in the serum and skin of aging mice. The comparison between multiple groups was performed by analysis of variance. Duncan's test was used for multiple comparisons. The remaining data were calculated and analyzed using GraphPad Prism 7.0 (Graph Pad Software, La Jolla, CA, USA) software, group differences were also analyzed by one-way analysis of variance (ANOVA) followed by Duncan's multiple comparison test. All of the values were expressed as mean \pm standard deviation $(\overline{\mathrm{X}} \pm \mathrm{SD})$, and a p-value $<0.05$ was considered significant.

\section{Results \\ Histopathology of Liver Finding}

Studies have found that skin damage caused by irradiation can cause inflammation in other organs, such as the liver, by regulating inflammatory factors in the blood. ${ }^{37}$ The liver structure of mice in the control group was normal (Figure 1). The liver cells were large and round, and there was no infiltration of inflammatory cells, representing the morphological characteristics of a normal liver. The arrangement of liver cells in the UVB group was more disordered than that in the control group. The liver cells around the central vein were partially necrotic, and there was inflammatory cell infiltration. The hepatocyte structure of the $\mathrm{VC}+\mathrm{UVB}$ group and $\mathrm{NMN}+\mathrm{UVB}$ group was improved compared with that of the UVB group. Among
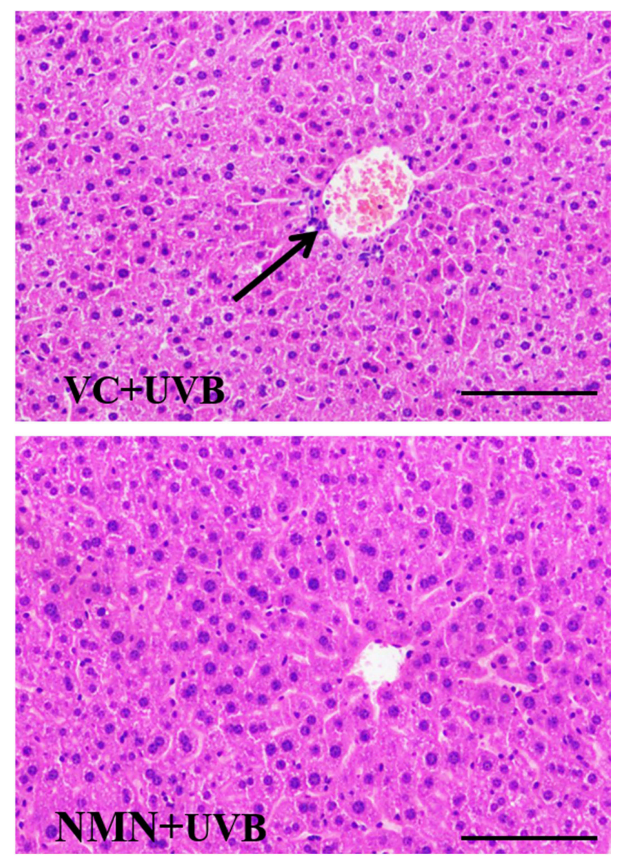

Figure I Photomicrograph of liver paraffin sections stain with (H\&E). The black bars indicate $200 \mu \mathrm{m}$. The black arrows indicate necrotic cells. Abbreviations: VC+UVB, mice treated with vitamin C $(300 \mathrm{mg} / \mathrm{kg})$ and UVB irradiation; NMN+UVB, mice treated with nicotinamide mononucleotide $(300 \mathrm{mg} / \mathrm{kg})$ and $U V B$ irradiation. 
them, the hepatocyte morphology of the NMN+UVB group was close to that of the control group.

\section{Histopathology of Skin Finding}

Histopathology results of skin can directly reflect the degrees of skin damage caused by UVB. Figure 2A, $\mathrm{D}$ and $\mathrm{E}$ shows that the skin of the mice in the control group had a normal structure: a thin epidermal layer, a wavy junction between the epidermis and the dermis, and no excessively keratinized stratum corneum, the epidermal was thinnest, and the dermis layer was thick. Compared with control group mice, in UVB group mice the thickness of the dermis layer was significantly thinned while the thickness of the epidermal layer increased $(\mathrm{p}<$ $0.05)$, the number of collagen fiber bundles was reduced, the subcutaneous tissue was disorderly arranged, and the boundary was not obvious. In addition, inflammatory cell infiltration around the appendages was seen, indicating that there was a chronic inflammation reaction in the skin and that long-term UVB irradiation could induce skin photoaging. The thickness of the skin dermis layer was increased, but the collagen fibers were loosely dispersed in the VC+UVB group compared with the UVB group. The thickness of the whole skin layer was significantly thicker in the mice in the NMN+UVB group than in those in the UVB group. The collagen fiber bundles were distributed relatively uniformly and orderly. The overall structure was close to that of the control group.

The collagen fibers are a blue-purple color after Masson staining. Figure $2 \mathrm{~B}$ shows that more collagen fibers were present and showed normal arrangement in the control group, but very few in the UVB group, indicating that UVB irradiation caused the degradation of collagen fibers. The number of collagen fibers in the skin dermis increased in the VC+UVB group and the NMN+UVB group compared with the UVB group. The collagen fibers in the NMN+UVB group were arranged neatly and orderly, and there was almost no shrinkage, breakage, or other changes relative to control.

According to the TB staining results (Figure $2 \mathrm{C}$ and $\mathrm{F}$ ), significantly more mast cells were present in the dermal layer in the UVB group $(p<0.05)$, indicating that UVB irradiation induced the production of mast cells in the skin, thereby resulting in skin inflammation. The VC+UVB group showed decreased mast cells in mouse skin than the UVB group. After the mice were treated with NMN, the mast cells in mouse skin were significantly reduced ( $\mathrm{p}$ $<0.05$ ), and the results were similar to the control group.

\section{Oxidative Stress Enzyme Investigation of Serum}

Increasing research has demonstrated that UVB irradiation will release ROS in the skin, which then affect the activity of oxidative enzyme both in skin and serum. ${ }^{38}$ Among the groups, the control group showed the highest serum T-SOD and CAT activity $(99.05 \pm 16.07$ and $40.73 \pm 4.62 \mathrm{U} / \mathrm{mL})$ and the lowest $\mathrm{H}_{2} \mathrm{O}_{2}$ and AGEs content $(15.52 \pm 3.47 \mathrm{mmol} / \mathrm{L}$ and $32.44 \pm 6.19 \mathrm{pg} / \mathrm{mL}$ ). However, the above indicators showed an opposite trend in the UVB group (T-SOD $48.64 \pm 7.87 \mathrm{U} /$ $\mathrm{mL}$; CAT $18.08 \pm 4.28 \mathrm{U} / \mathrm{mL} ; \mathrm{H}_{2} \mathrm{O}_{2} 61.57 \pm 10.07 \mathrm{mmol} / \mathrm{L}$; AGEs $131.62 \pm 9.89 \mathrm{pg} / \mathrm{mL}$ ), and a significant difference was found in these two groups $(\mathrm{p}<0.05)$ (Table 2). Compared with UVB treatment alone, VC and NMN treatment significantly increased the activity of T-SOD and CAT enzymes in the serum of mice and significantly decreased the contents of $\mathrm{H}_{2} \mathrm{O}_{2}$ and AGEs $(\mathrm{p}<0.05)$. It is worth noting that the levels of T-SOD $(198.92 \pm 21.26 \mathrm{U} / \mathrm{mL})$, CAT $(34.15 \pm 5.58 \mathrm{U} / \mathrm{mL})$, $\mathrm{H}_{2} \mathrm{O}_{2}(27.35 \pm 4.79 \mathrm{mmol} / \mathrm{L})$, and AGEs $(29.69 \pm 8.11 \mathrm{pg} / \mathrm{mL})$ in the serum of mice in the NMN+UVB group were similar to those in the control group, and the enzyme activity of T-SOD in the NMN+UVB group was significantly higher than that in the control group ( $p<0.05$ ), indicating that NMN greatly increased the activity of serum antioxidant enzymes in mice.

\section{Oxidative Stress Enzyme Investigation of Skin}

Previous studies have also found that UV irradiation promotes the depletion of $\mathrm{Na}^{+}-\mathrm{K}^{+}$-ATPase and NADK, and increases the content of AGEs in the skin. ${ }^{39,40}$ Table 3 shows that the levels of T-SOD, CAT, $\mathrm{Na}^{+}-\mathrm{K}^{+}$-ATPase, NADK, $\mathrm{H}_{2} \mathrm{O}_{2}$ and AGEs in the mouse skin tissues in the control group were respectively $27.69 \pm 6.32 \mathrm{U} / \mathrm{mgprot}$, $24.24 \pm 3.11 \mathrm{U} / \mathrm{mgprot}, 0.89 \pm 0.13 \mathrm{U} / \mathrm{mgprot}, 17.47 \pm 2.66$ $\mathrm{nmol} / \mathrm{min} / \mathrm{mg}$-prot, $10.99 \pm 1.19 \mathrm{mmol} / \mathrm{gprot}$, and 366.76 $\pm 7.24 \mathrm{pg} / \mathrm{mL}$. These indicators are significantly different in the UVB group (T-SOD 7.51 $\pm 1.19 \mathrm{U} /$ mgprot; CAT $14.58 \pm 3.54$ U/mgprot; Na+-K+-ATPase $0.20 \pm 0.04 \mathrm{U} /$ mgprot; NADK $12.97 \pm 0.69 \mathrm{nmol} / \mathrm{min} /$ mgprot; $\mathrm{H}_{2} \mathrm{O}_{2}$ $14.09 \pm 1.66 \mathrm{mmol} / \mathrm{gprot}$; and AGEs $451.02 \pm 55.35 \mathrm{pg} / \mathrm{mL}$ ) $(p<0.05)$. The above serum indexes were improved to varying degrees in the mice in the $\mathrm{VC}+\mathrm{UVB}$ group and the NMN+UVB group compared with those in the UVB group. Additionally, besides T-SOD and $\mathrm{Na}+-\mathrm{K}+-\mathrm{ATPase}$, there was no obvious difference in the above serum 

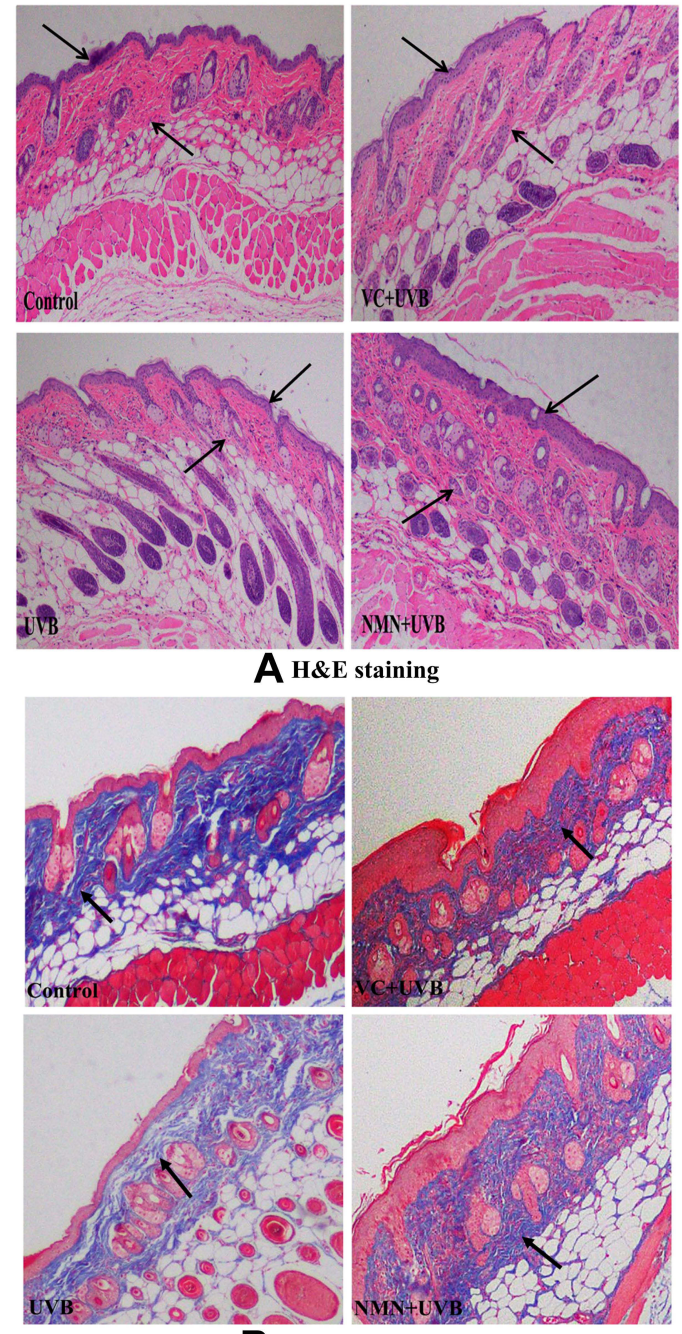

B Masson staining
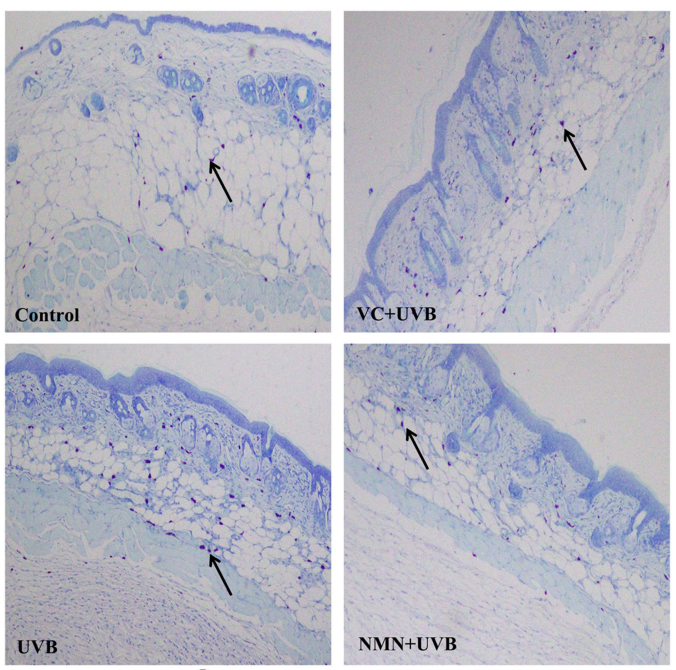

C Toluidine blue staining

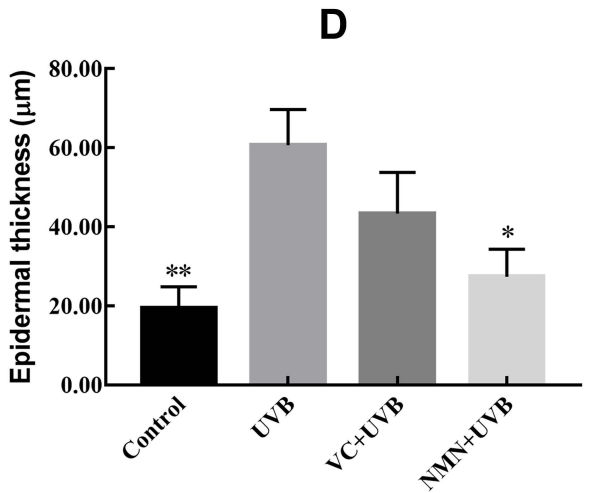

E

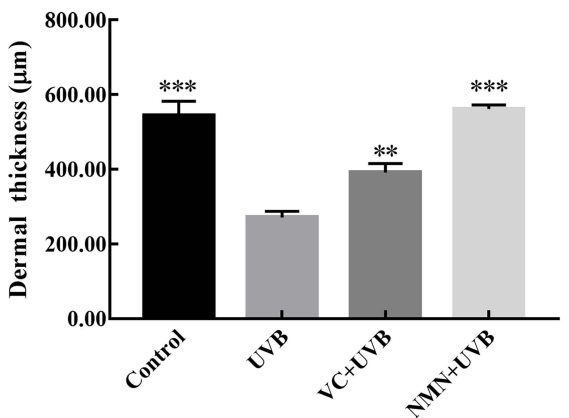

$\mathbf{F}$

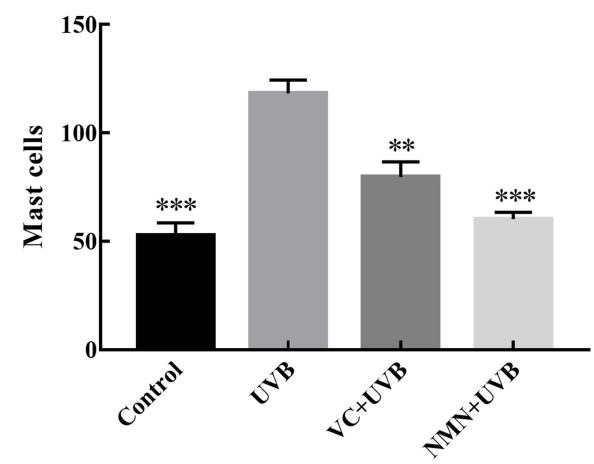

Figure 2 Photomicrograph of skin paraffin sections. (A) H\&E staining of the skin; (B) Masson's staining of the skin; (C) toluidine blue staining; (D) epidermal thickness of skin; (E) dermal thickness of skin; (F) number of mast cells of skin. ${ }^{*} p<0.05$ compared to the UVB group; ${ }^{* *} p<0.0$ l compared to UVB group; ${ }^{* * *} p<0.00 \mathrm{I}$ compared to the UVB group. $\rightarrow \leftarrow$ in $(\mathbf{A})$ indicate the thickness of dermis; $\uparrow$ in (B) indicate collagen fiber; $\uparrow$ in (C) indicate mast cell.

Abbreviations: VC+UVB, mice treated with vitamin $\mathrm{C}(300 \mathrm{mg} / \mathrm{kg})$ and UVB irradiation; NMN+UVB, mice treated with nicotinamide mononucleotide $(300 \mathrm{mg} / \mathrm{kg})$ and $U V B$ irradiation. 
Table 2 Levels of Oxidative Stress Indicators in Serum of Mice ${ }^{A}$

\begin{tabular}{|l|c|c|c|c|}
\hline Group & T-SOD $(\mathbf{U} / \mathbf{m L})$ & CAT $(\mathbf{U} / \mathbf{m L})$ & H $_{2} \mathbf{O}_{2}(\mathbf{m m o l} / \mathbf{L})$ & AGEs $(\mathbf{p g} / \mathbf{m L})$ \\
\hline Control & $99.05 \pm 16.07^{\mathrm{b}}$ & $40.73 \pm 4.62^{\mathrm{a}}$ & $15.52 \pm 3.47^{\mathrm{d}}$ & $32.44 \pm 6.19^{\mathrm{c}}$ \\
UVB & $48.64 \pm 7.87^{\mathrm{c}}$ & $18.08 \pm 4.28^{\mathrm{d}}$ & $61.57 \pm 10.07^{\mathrm{a}}$ & $131.62 \pm 9.89^{\mathrm{a}}$ \\
VC+UVB & $81.87 \pm 11.86^{\mathrm{b}}$ & $23.46 \pm 4.25^{\mathrm{c}}$ & $39.15 \pm 7.60^{\mathrm{b}}$ & $113.53 \pm 12.34^{\mathrm{b}}$ \\
NMN+UVB & $198.92 \pm 21.26^{\mathrm{a}}$ & $34.15 \pm 5.58^{\mathrm{b}}$ & $27.35 \pm 4.79^{\mathrm{c}}$ & $29.69 \pm 8.11^{\mathrm{c}}$ \\
\hline
\end{tabular}

Notes: ${ }^{A}$ Values are mean \pm standard deviation $\left(\mathrm{N}=10 /\right.$ group). The difference in variance between the two groups was significant $(p<0.05)$. ${ }^{a-d}$ Mean values with different letters in the same column are significantly different $(p<0.05)$ according to Duncan's honestly significantly different test.

Abbreviations: UVB, mice treated with UV irradiation; VC+UVB, mice treated with vitamin C (300 mg/kg) and UV irradiation; NMN+UVB, mice treated with nicotinamide mononucleotide $(300 \mathrm{mg} / \mathrm{kg})$ and UV irradiation; T-SOD, total superoxide dismutase; CAT, catalase; $\mathrm{H}_{2} \mathrm{O}_{2}$, hydrogen peroxide; AGEs, advanced glycation end products.

Table 3 Levels of Oxidative Stress in Skin of Mice ${ }^{B}$

\begin{tabular}{|c|c|c|c|c|c|c|}
\hline Group & $\begin{array}{c}\text { T-SOD } \\
\text { (U/mgprot) }\end{array}$ & $\begin{array}{c}\text { CAT } \\
\text { (U/mgprot) }\end{array}$ & $\begin{array}{c}\mathrm{H}_{2} \mathrm{O}_{2} \\
\text { (mmol/gprot) }\end{array}$ & AGEs $(\mathrm{pg} / \mathrm{mL})$ & $\begin{array}{c}\mathrm{Na}^{+}-\mathrm{K}^{+} \text {-ATPase } \\
\text { (U/mgprot) }\end{array}$ & $\begin{array}{c}\text { NADK (nmol/ } \\
\mathrm{min} / \mathrm{mgprot} \text { ) }\end{array}$ \\
\hline Control & $27.69 \pm 6.32^{\mathrm{a}}$ & $24.24 \pm 3.11^{\mathrm{a}}$ & $10.99 \pm 1.19^{\mathrm{b}}$ & $366.76 \pm 7.24^{b c}$ & $0.89 \pm 0.13^{a}$ & $17.47 \pm 2.66^{\mathrm{a}}$ \\
\hline UVB & $7.51 \pm 1.19^{c}$ & $14.58 \pm 3.54^{b}$ & $14.09 \pm 1.66^{\mathrm{a}}$ & $451.02 \pm 55.35^{\mathrm{a}}$ & $0.20 \pm 0.04^{d}$ & $12.97 \pm 0.69^{c}$ \\
\hline$V C+U V B$ & $17.01 \pm 3.93^{b}$ & $21.84 \pm 4.53^{\mathrm{a}}$ & $13.50 \pm 2.44^{\mathrm{a}}$ & $405.36 \pm 26.62^{b}$ & $0.49 \pm 0.14^{c}$ & $14.58 \pm 1.47^{b}$ \\
\hline$N M N+U V B$ & $20.06 \pm 3.07^{b}$ & $22.66 \pm 4.59^{\mathrm{a}}$ & $8.46 \pm 1.99^{b}$ & $339.61 \pm 43.18^{c}$ & $0.66 \pm 0.12^{b}$ & $16.48 \pm 1.57^{\mathrm{a}}$ \\
\hline
\end{tabular}

Notes: ${ }^{B}$ Values are mean \pm standard deviation $\left(N=10 /\right.$ group). The difference in variance between the two groups was significant $(p<0.05) .{ }^{a-d}$ Mean values with different letters in the same column are significantly different $(p<0.05)$ according to Duncan's honestly significantly different test.

Abbreviations: UVB, mice treated with UV irradiation; VC+UVB, mice treated with vitamin C (300 mg/kg) and UV irradiation; NMN+UVB, mice treated with nicotinamide mononucleotide $(300 \mathrm{mg} / \mathrm{kg})$ and $\mathrm{UV}$ irradiation; T-SOD, total superoxide dismutase; CAT, catalase; $\mathrm{H}_{2} \mathrm{O}_{2}$, hydrogen peroxide; AGEs, advanced glycation end products; NADK, nicotinamide adenine dinucleotide kinase.

indexes between the mice treated with NMN and those in the mice of the control group ( $\mathrm{p}>0.05)$.

\section{Inflammatory Cytokine Results}

A large amount of ROS produced by UVB irradiation will further induce inflammation in the skin. ${ }^{41}$ Table 4 shows that among the groups, the UVB group showed the highest levels of the proinflammatory cytokines TNF- $\alpha$, IL- $1 \beta$, and IL- 6 in the serum and skin and the lowest levels of the antiinflammatory cytokines IL-4 and IL-10. A significant difference was found between the UVB group and the control group $(\mathrm{p}<0.05)$. Compared with UVB treatment alone, VC treatment improved the contents of some cytokines in serum and skin, but no significant differences were observed on the levels of serum IL-4, skin TNF- $\alpha$, IL-6, and IL-10 ( $p>0.05$ ). It is worth noting that NMN treatment significantly decreased the

Table 4 Levels of Inflammatory Indexes in Serum and Skin of Mice ${ }^{C}$

\begin{tabular}{|c|c|c|c|c|c|}
\hline \multicolumn{6}{|c|}{ Serum Levels } \\
\hline Group & TNF- $\alpha$ (ng/L) & IL-I $\beta$ (ng/L) & IL-4 (pg/L) & IL-6 (pg/mL) & IL-I 0 (pg/mL) \\
\hline Control & $238.87 \pm 67.66^{\mathrm{b}}$ & $17.83 \pm 1.17^{c}$ & $102.14 \pm 15.80^{\mathrm{a}}$ & $16.04 \pm 4.69^{c}$ & $320.38 \pm 47.29^{a}$ \\
\hline UVB & $550.60 \pm 83.35^{\mathrm{a}}$ & $21.87 \pm 1.42^{\mathrm{a}}$ & $59.1 I \pm 8.4 I^{c}$ & $75.78 \pm 8.46^{\mathrm{a}}$ & $128.73 \pm 21.54^{c}$ \\
\hline$V C+U V B$ & $317.87 \pm 60.20^{b}$ & $20.12 \pm 1.18^{b}$ & $57.88 \pm 9.30^{c}$ & $50.12 \pm 8.02^{b}$ & $135.54 \pm 10.48^{c}$ \\
\hline NMN+UVB & $250.27 \pm 51.28^{b}$ & $17.95 \pm\left. 1.1\right|^{c}$ & $71.40 \pm 10.87^{b}$ & $17.33 \pm 6.75^{c}$ & $179.35 \pm 50.09^{b}$ \\
\hline \multicolumn{6}{|c|}{ Skin Levels } \\
\hline Control & $99.34 \pm 14.92^{b}$ & $6.34 \pm 0.69^{c}$ & $|34.45 \pm 23.7|^{a}$ & $34.67 \pm 4.65^{b}$ & $653.74 \pm 68.16^{\mathrm{a}}$ \\
\hline UVB & $|58.79 \pm| 4.03^{\mathrm{a}}$ & $15.20 \pm 1.16^{\mathrm{a}}$ & $41.06 \pm 6.94^{d}$ & $50.79 \pm 7.30^{\mathrm{a}}$ & $95.71 \pm 19.20^{c}$ \\
\hline$V C+U V B$ & $151.18 \pm 26.87^{\mathrm{a}}$ & $9.43 \pm 2.30^{\mathrm{b}}$ & $69.80 \pm 14.44^{c}$ & $47.43 \pm 5.20^{\mathrm{a}}$ & $|4| .9 \mid \pm 35.56^{c}$ \\
\hline NMN+UVB & $95.63 \pm 18.98^{b}$ & $5.28 \pm 0.63^{c}$ & $89.97 \pm 6.08^{b}$ & $31.22 \pm 8.03^{b}$ & $271.39 \pm 35.4 I^{\mathrm{b}}$ \\
\hline
\end{tabular}

Notes: ${ }^{c}$ Values are mean \pm standard deviation $\left(\mathrm{N}=10\right.$ /group). The difference in variance between the two groups was significant $(p<0.05)$. ${ }^{a-d}$ Mean values with different letters in the same column are significantly different $(p<0.05)$ according to Duncan's honestly significantly different test.

Abbreviations: UVB, mice treated with UV irradiation; VC+UVB, mice treated with vitamin $C(300 \mathrm{mg} / \mathrm{kg})$ and UV irradiation; NMN+UVB, mice treated with nicotinamide mononucleotide $(300 \mathrm{mg} / \mathrm{kg})$ and UV irradiation; TNF- $\alpha$, tumor necrosis factor- $\alpha$; IL-I $\beta$, interleukin-I $\beta$; IL-4, interleukin-4; IL-6, interleukin-6; IL-I0, interleukin-I0. 
levels of TNF- $\alpha$, IL- $1 \beta$, and IL-6, and increased IL-4 and IL10 levels in serum and skin of mice when compared with the UVB group $(p<0.05)$, which indicated that the inflammation indicators of the $\mathrm{NMN}+\mathrm{UVB}$ group were improved more than those of the $\mathrm{VC}+\mathrm{UVB}$ group.

\section{mRNA Expression of Oxidative Genes}

To further evaluate the antioxidant effect of NMN on UVB-induced skin damage in mice, we determined the gene expression levels of SOD1, SOD2, CAT, and GSH in the liver and skin of mice. In Figure 3, the mRNA expression levels of SOD1, SOD2, CAT, and GSH in the skin and liver of UVB group mice decreased significantly compared with those in control group mice $(p<0.05)$. Although the mRNA expression levels of SOD1, SOD2, $\mathrm{CAT}$, and GSH in the skin and liver increased to a certain degree in the $\mathrm{VC}+\mathrm{UVB}$ group, there was no significance between the UVB group and $\mathrm{VC}+\mathrm{UVB}$ group besides the SOD1 and SOD2 levels in the liver $(p>0.05)$. However, the mRNA expression levels of the above indicators in the $\mathrm{NMN}+\mathrm{UVB}$ group were higher than those in the UVB group and were similar to those in the control group, which is in line with the oxidative indicators in serum and skin.

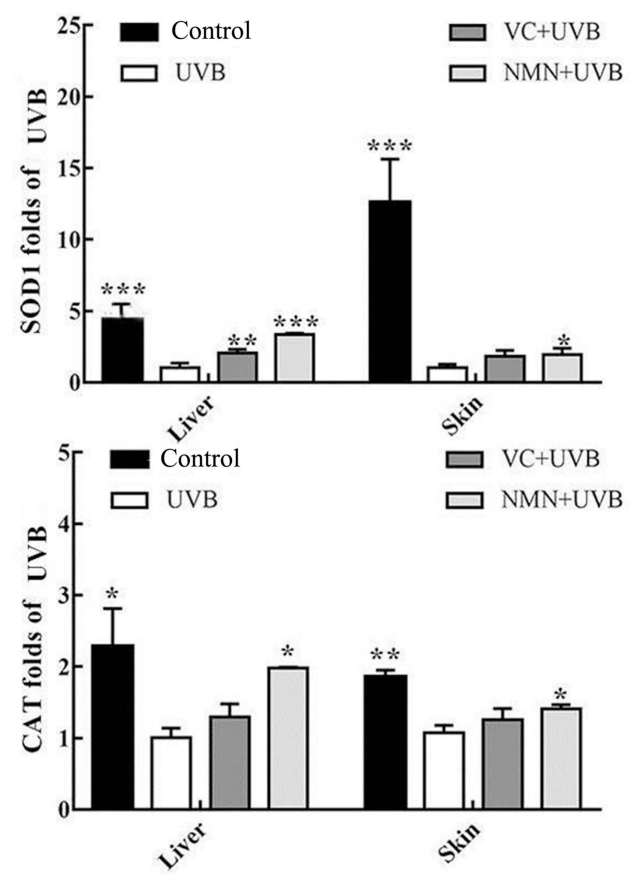

\section{mRNA Expression of Inflammatory Genes}

As shown in Figure 4, compared with the control group, UVB irradiation increased the mRNA expression level of NF- $\kappa B p 65$ in mouse skin and liver and reduced the expres-

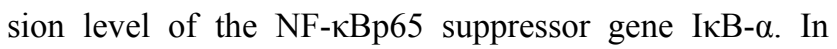
addition, the expression of IL-10, a factor related to the NF-kBp65 signaling pathway, was also downregulated, and the most significant change was the upregulation of the expression of TNF- $\alpha$ and IL-6. Compared with UVB group, the mRNA expression levels of IкB- $\alpha$ and IL-10 in the skin and liver were significantly increased in the NMN $+\mathrm{UVB}$ group, while the expression levels of NF- $\mathrm{kBp} 65$, TNF- $\alpha$ and IL- 6 decreased $(\mathrm{p}<0.05)$. Additionally, the mRNA expression levels of the above indicators in the NMN+UVB group were close to those in the control group.

\section{mRNA Expression of AMPK Signaling Pathway Related Genes}

The AMPK signaling pathway is considered to be an important pathway in regulating the repair of UVBinduced DNA damage. SIRT1, LKB1, PGC-1 $\alpha$, APPL1, FOXO, and mTOR all belong to the AMPK pathway. ${ }^{42,43}$

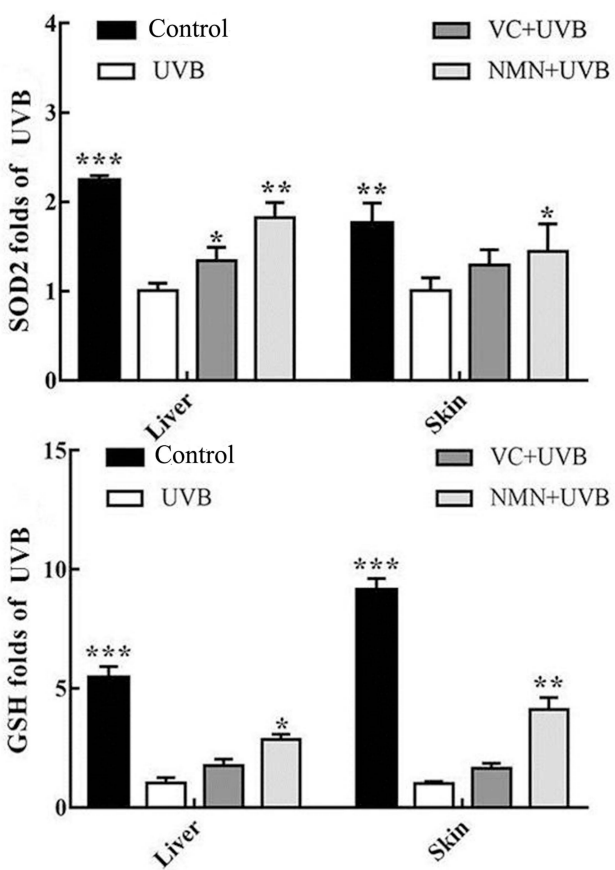

Figure 3 Gene expression of SODI, SOD2, CAT and GSH in skin and liver tissues. * $p<0.05$ compared to the UVB group; $* * p<0.0$ I compared to UVB group; $* * * p<0.00$ I compared to the UVB group.

Abbreviations: VC+UVB, mice treated with vitamin $\mathrm{C}(300 \mathrm{mg} / \mathrm{kg})$ and UVB irradiation; NMN+UVB, mice treated with nicotinamide mononucleotide $(300 \mathrm{mg} / \mathrm{kg})$ and UVB irradiation. 

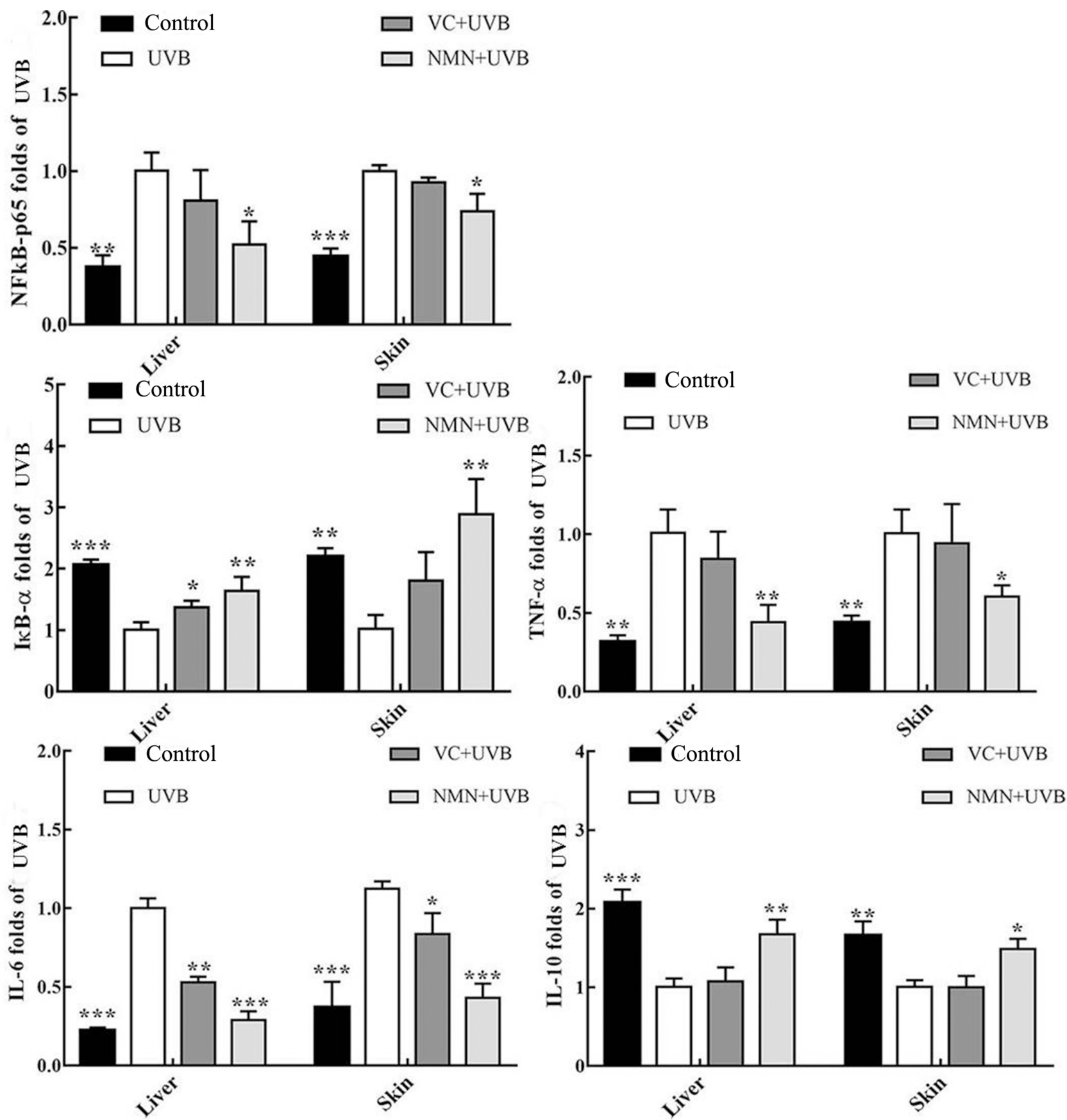

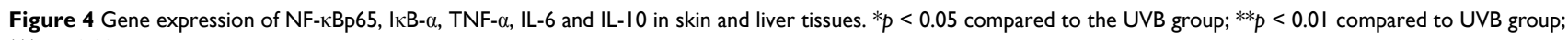
$* * * p<0.001$ compared to the UVB group.

Abbreviations: VC+UVB, mice treated with vitamin C $(300 \mathrm{mg} / \mathrm{kg})$ and UVB irradiation; NMN+UVB, mice treated with nicotinamide mononucleotide (300mg/kg) and UVB irradiation.

As illustrated in Figure 5, the control group showed the highest gene expression of AMPK, SIRT1, LKB1, PGC$1 \alpha$, APPL1, and FOXO in the skin (11.58-, 1.54-, 7.35-, 1.53-, 1.47-, and 8.12-fold higher than those in the UVB group) and liver (5.46-, 3.43-, 2.71-, 1.96-, 2.44-, and 3.23-fold higher than those in the UVB group) and the lowest expression level of mTOR (0.28-fold and 0.14 - fold). The levels of the above genes in the skin and liver of the UVB group mice were opposite to those in the control group mice, and a significant difference was found between these two groups $(\mathrm{p}<0.05)$. After $\mathrm{VC}$ treatment, the mRNA expression of AMPK, SIRT1, LKB1, PGC-1 $\alpha$, APPL1, and FOXO in the skin and liver increased, while the expression of mTOR decreased, but 

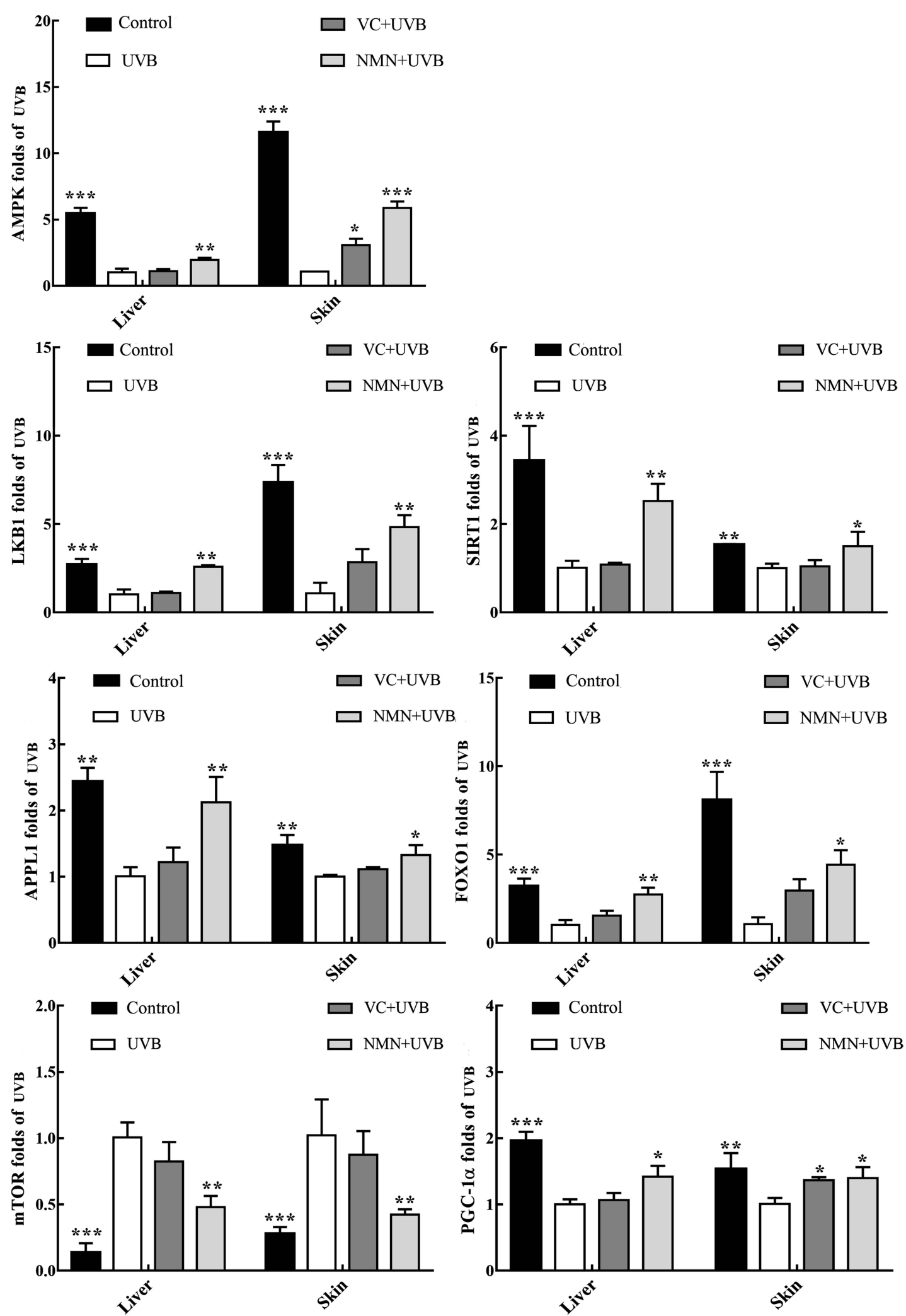

Figure 5 Gene expression of AMPK, SIRTI, LKBI, PGC-I $\alpha$, APPLI, mTOR and FOXO in skin and liver tissues. $* p<0.05$ compared to the UVB group; **p $<0.01$ compared to UVB group; ***p $<0.001$ compared to the UVB group.

Abbreviations: VC+UVB, mice treated with vitamin $\mathrm{C}(300 \mathrm{mg} / \mathrm{kg})$ and UVB irradiation; NMN+UVB, mice treated with nicotinamide mononucleotide $(300 \mathrm{mg} / \mathrm{kg})$ and UVB irradiation. 
there was no significant difference was found between the UVB group and VC+UVB group besides AMPK and PGC-1 $\alpha$. The expression levels of the above indicators in the skin (5.87-, 1.50-, 4.84-, 1.40-, 1.33-, 4.44-, and 0.42fold of those in the UVB group) and liver (1.96-, 2.52-, 2.58-, 1.42-, 2.12-, 2.75-, and 0.48-fold of those in the UVB group) of NMN+UVB group were significantly different from UVB group and close to those in the control group.

\section{Protein Expression}

We used Western blotting to determine the protein expression of AMPK, NFкB-p65, IкB- $\alpha$, SOD1, and CAT, which are representative proteins related to oxidant and inflammation. As shown in Figure 6, the protein expression of AMPK, I $\mathrm{B}-\alpha$, SOD1, and CAT in the skin tissues of the UVB group was significantly lower than that of the control group (6.07-, 1.31-, 2.87- and 1.38-fold higher than those in the UVB group), while NFkB-p65 was significantly higher in the UVB group than in the control group (0.47fold lower than that in the UVB group) $(p<0.05)$. The expression levels of AMPK, I $\mathrm{B}-\alpha$, SOD1, and CAT in the mouse skin tissues increased, while the protein expression of NFKB-p65 decreased in the VC+UVB group (1.04- fold, 0.88-fold, 1.21-fold, 1.38-fold, and 0.84-fold) and NMN+UVB group (3.01-fold, 1.17-fold, 1.56-fold, 1.1.41fold, and 0.76-fold) compared with the UVB group. The expression levels of the above indicators in the NMN + UVB group were similar to those in the control group.

\section{Discussion}

In the present study, the effect of intraperitoneal injection of NMN on mice with UVB-induced skin damage was explored. The results showed that at a macro level, NMN maintained the normal structure of skin and liver, and regulate the levels of oxidation and inflammation indicators in serum and skin tissue. At a micro level, NMN reduces the inflammation damage and energy metabolism disorder caused by UVB to the skin by regulating signal pathways such as NF- $\kappa \mathrm{B}$ and AMPK. Overall, the results in the present study are similar to our previous study where NMN was given by oral gavage.

Long-term skin exposure to ultraviolet radiation causes premature aging, inducing wrinkles, stains and laxity, and even benign or malignant tumors. Histopathological observations can be used to quickly evaluate the seriousness of skin damage caused by ultraviolet radiation. ${ }^{44}$ The previous study revealed that the thickness of the epidermal
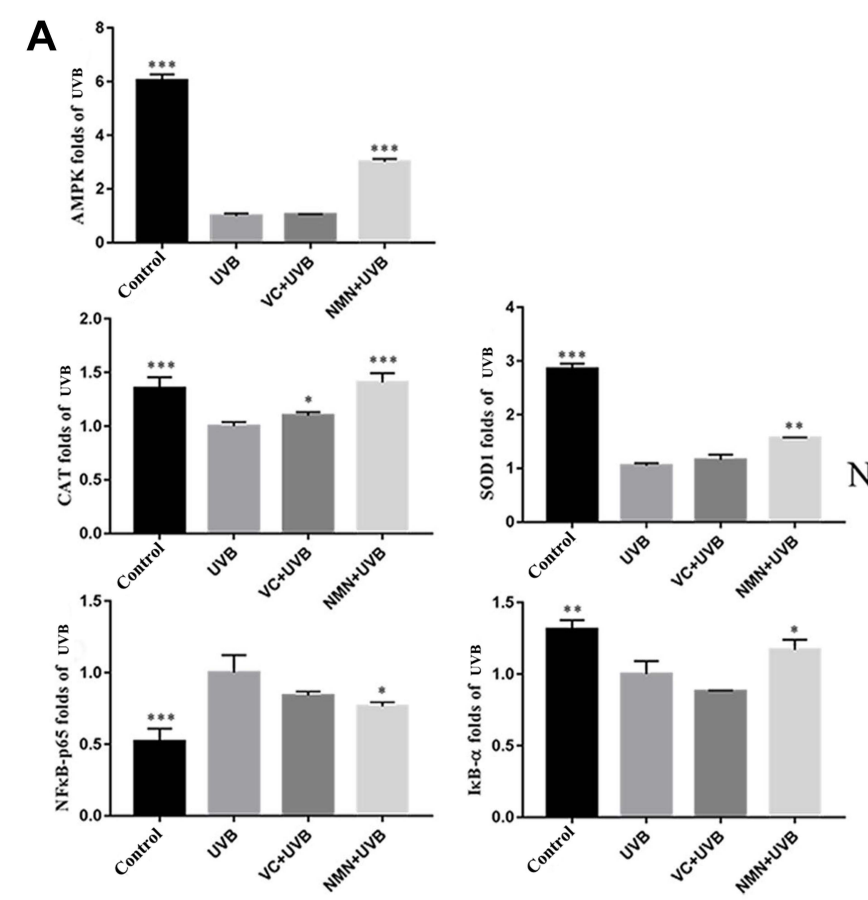

B

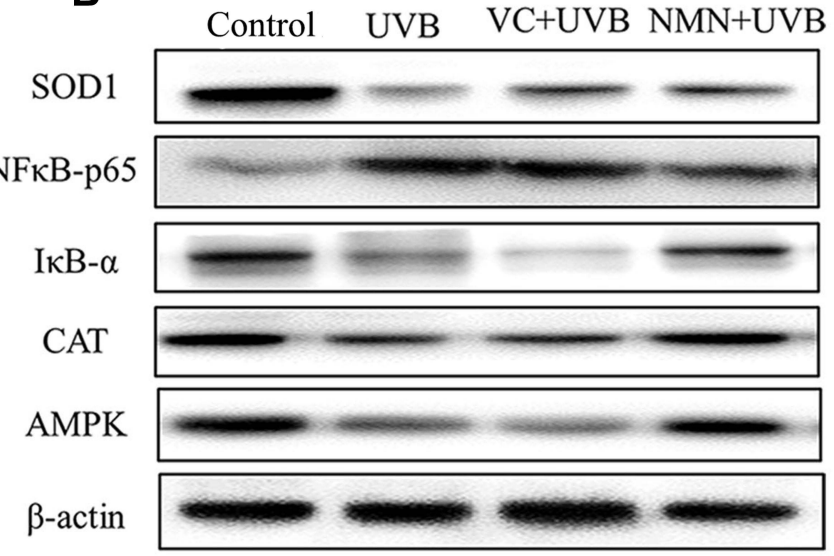

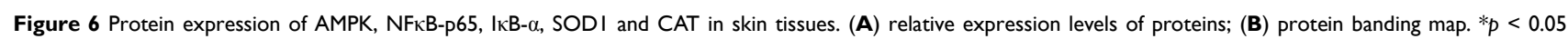
compared to the UVB group; ${ }^{*} p<0.01$ compared to the UVB group; $* * * p<0.001$ compared to the UVB group.

Abbreviations: $V C+U V B$, mice treated with vitamin $C(300 \mathrm{mg} / \mathrm{kg})$ and UVB irradiation; NMN+UVB, mice treated with nicotinamide mononucleotide $(300 \mathrm{mg} / \mathrm{kg})$ and $U V B$ irradiation. 
layer increased while the dermis of the skin decreased, the number of collagen fibers decreased, and the number of mast cells increased after the skin was irradiated by $\mathrm{UVB},{ }^{45,46}$ which is in line with our results. Other research found UVB irradiation significantly reduced GSH content and P450 isoenzymes activity in the liver, which may be related to the "bystander effect". ${ }^{47,48}$ After intraperitoneal injection of NMN to the mice, we found the pathological morphology of skin exposed to UVB was greatly improved when compared to control skin exposed to UVB, and the livers of the mice also maintained normal morphology without obvious damage. It has been reported that NAD+ levels will decline in organs such as liver, skin, brain, and heart with age, ${ }^{49}$ but $\mathrm{NAD}^{+}$level increased after administration with NMN in this study. This may explain our histopathological morphological findings on skin and liver of UVB-induced skin damage mice.

Disordered oxidation-antioxidant balance in the human body is closely related to the occurrence and development of aging. Long-term UVB irradiation induces a severe oxidative stress response, thereby accelerating the aging of the skin. ${ }^{50}$ Superoxide dismutase (SOD), Catalase (CAT), and Glutathione (GSH) act as antioxidants in the body, their enzymatic activity closely related to aging, biosynthesis, degradation, and defense. ${ }^{51-53}$ As an important marker of skin aging, advanced glycation endproducts (AGEs) are closely related to oxidative stress and cytokine release. Accumulation of AGEs will cause increased brittleness of collagen. ${ }^{54}$ Intracellular hydrogen peroxide $\left(\mathrm{H}_{2} \mathrm{O}_{2}\right)$ levels are decomposed by CAT. An early study found UVB-irradiation downregulated CAT expression and increased $\mathrm{H}_{2} \mathrm{O}_{2}$ level. ${ }^{55}$ One study showed that NMN administration upregulated the protein expression of SOD2 in hippocampal tissue of mice by increasing the NADK levels. ${ }^{10}$ Similarly, our study also found that NMN intraperitoneal injection can help maintain relatively normal levels of T-SOD, CAT, AGEs, and $\mathrm{H}_{2} \mathrm{O}_{2}$ in mouse skin tissue. Notably, NMN can also greatly increase serum levels of T-SOD and CAT. Additionally, the enzyme activity of T-SOD in the NMN+UVB group was even higher than that in the control group. NMN can also upregulate the mRNA expression of SOD1, SOD2, CAT, and GSH and the protein expression of SOD1 and CAT in skin and liver tissues. This finding shows that NMN can improve not only the skin damage by adjusting the oxidative stress level of the body but also the overall antioxidant level of the body from the perspective of the serum and liver.
Studies have shown that UVB irradiation can cause a decrease in NADK in skin tissue. ${ }^{56}$ The oral administration of NMN, a precursor of NADK, can increase the level of NADK in skin tissue, thereby preventing skin cancer caused by UVB irradiation. ${ }^{57}$ The regulation of $\mathrm{Na}^{+}-\mathrm{K}^{+}$ATPase enzyme activity can provide cells with the necessary vitality. A decrease in $\mathrm{Na}^{+}-\mathrm{K}^{+}$-ATPase activity will lead to impaired intracellular energy production and ion transport, thus affecting cell function and promoting aging. ${ }^{16}$ This experiment found that the levels of NADK and $\mathrm{Na}^{+}-\mathrm{K}^{+}$-ATPase in mouse skin tissue decreased significantly in the UVB group when compared to the control group, indicating that UVB irradiation causes skin energy metabolism disorders. After intraperitoneal injection with $\mathrm{NMN}$, levels of NADK and $\mathrm{Na}^{+}-\mathrm{K}^{+}$-ATPase in irradiated skin increased significantly and were similar to those in the control group. Studies have shown that mammals can convert NMN into NADK, which may indicate that intraperitoneal injection with $\mathrm{NMN}$ in our study played a role in improving skin injury by promoting the synthesis of NMN into NADK. ${ }^{58}$

When the skin is exposed to ultraviolet rays for a long time, inflammation symptoms such as dryness, itching, erythema, and edema occur. ${ }^{59}$ A surprising discovery in this experiment was that NMN upregulates the expression of NF-kappa-B inhibitor- $\alpha(\mathrm{I} \kappa \mathrm{B}-\alpha)$ in skin and liver tissues, thereby further inhibiting the activation of the NF $\kappa$ B-p65 signaling pathway. Nuclear factor- $\kappa \mathrm{B}(\mathrm{NF}-\kappa \mathrm{B})$ is an important transcription factor in the body's immune response. Normally, it is combined with its inhibitory protein $\mathrm{I} \kappa \mathrm{B}$ and therefore inactive. ${ }^{60}$ Studies have found that stressful conditions induce the phosphorylation of $\mathrm{I} \kappa \mathrm{B}$ protein, which subsequently activates NF- $\mathrm{B}$, and activated $\mathrm{NF}-\kappa \mathrm{B}$ further promotes the release of the proinflammatory cytokines tumor necrosis (TNF)- $\alpha$, interleukin (IL)-6, interleukin (IL)-12, and amongst other. ${ }^{61}$ The NF$\kappa \mathrm{B}$ signaling dysfunction commonly occurs in skin damage. ${ }^{62} \mathrm{I} \kappa \mathrm{B}-\alpha$ is a repressor protein of NF- $\kappa \mathrm{B}$ that can mask the nuclear localization signal of NF- $\kappa \mathrm{B}$ so that NF$\kappa \mathrm{B}$ exists in the cell as an inactive compound. ${ }^{63}$ Studies have shown that almost all NF- $\kappa \mathrm{B}$ inducers rapidly activate $\mathrm{NF}-\kappa \mathrm{B}$ due to the degradation of $\mathrm{I} \kappa \mathrm{B}-\alpha$, so it is possible to prevent the activation of $\mathrm{NF}-\kappa \mathrm{B}$ by preventing the phosphorylation of $I \kappa \mathrm{B}-\alpha{ }^{64}$ This study found that after UVB irradiation, the gene and protein expression of NFкB-p65 in mouse skin and liver tissues were increased significantly, and the mRNA and protein expression of IкB- $\alpha$ was decreased significantly, consistent with 
previous findings. ${ }^{65,66}$ On the other hand, NMN can alleviate inflammation in mice by balancing the expression of NF $\kappa$ B-p65 and I $\kappa$ B- $\alpha$. Other studies have also shown that NMN is beneficial in inflammation-related diseases. ${ }^{67}$

Both TNF- $\alpha$ and IL- 6 are proinflammatory cytokines in the NF- $\kappa \mathrm{B}$ signaling pathway. Among them, tumor necrosis factor- $\alpha(\mathrm{TNF}-\alpha)$ can induce NF- $\kappa \mathrm{B}$ activation in different types of cells. ${ }^{68}$ IL-6 is a multidirectional proinflammatory cytokine with biological activity. The role of IL-6 is similar to that of interleukin (IL)-1 $\beta$, both being key mediators of the inflammatory response. IL-6 can also activate the NF- $\mathrm{B}$ signaling pathway to a certain extent, causing chronic inflammation in the skin. In addition, overexpression of IL-6 can increase the permeability of the skin, promote inflammatory factors to infiltrate into the inflammation site, and initiate inflammation. ${ }^{68,69}$ IL-10 is an important cytokine related to inflammation secreted by macrophages, dendritic cells, and $\mathrm{T}$ cells. It can inhibit the activation of NF- $\kappa \mathrm{B}$ during inflammation and upregulate the ratio of IL-1RA/IL- $1 \beta .^{70}$ In this study, NMN downregulated the mRNA expression of the proinflammatory cytokines TNF- $\alpha$ and IL- 6 in the serum and skin tissue, and upregulated the expression of the inflammatory cytokine IL-10, thereby reducing the degree of inflammatory damage induced by these inflammatory mediators in skin-damaged mice.

AMP-activated protein kinase (AMPK) is widely present in various eukaryotic cells and plays an important role in maintaining the balance of energy metabolism in cells. ${ }^{71}$ There are also many reports on the AMPK signaling pathway's role in host defense, such as infection, oxidative stress, inflammation, and immunity. In young cells, high expression levels of AMPK promote the activity of factors such as silent information regulator 1 (SIRT1), peroxisome proliferator-activated receptor $\gamma$ co-activator- $1 \alpha$ (PGC- $1 \alpha)$ and forkhead transcription factor O (FOXO), thereby inhibiting the activity of $\mathrm{NF}-\kappa \mathrm{B} .{ }^{72}$ Endoplasmic reticulum stress and oxidative stress are effective inducers of NF$\kappa \mathrm{B}$ signaling, while AMPK plays a role in protecting cells from mitochondrial dysfunction and inhibiting endoplasmic reticulum stress and oxidative stress. NF- $\kappa \mathrm{B}$ signaling is enhanced due to decreased AMPK activity during cell aging. ${ }^{73}$ Studies have shown that UVB irradiation can inhibit the activation of AMPK, thereby aggravating DNA damage and inflammatory damage. ${ }^{42}$ We also obtained the same results that the relative mRNA and

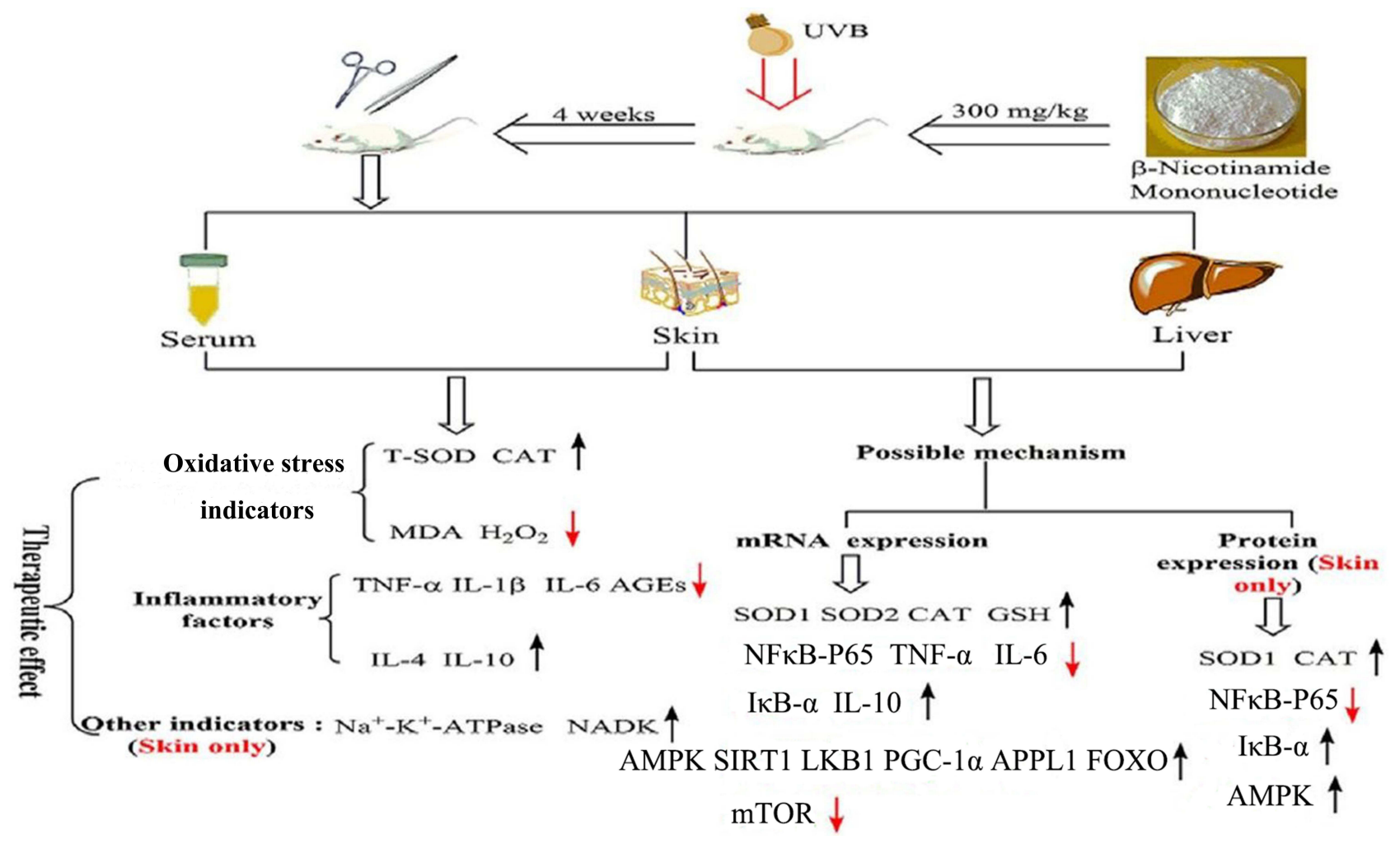

Figure 7 The possible mechanism of this study. The black arrows " $\uparrow$ " indicated those indicators were increased after intraperitoneal injection treatment with NMN, but the red arrows " $\downarrow$ " indicated those indicators were decreased after intraperitoneal injection treatment with NMN. 
protein expression of AMPK in the liver and skin of the UVB group mice was significantly lower than that of the control group. However, after intraperitoneal injection with NMN, the expression levels of AMPK in liver and skin tissues increased significantly. Other studies also revealed that NMN activated AMPK via increasing the level of NADK. ${ }^{74}$

In the process of exploring the protective effect of NMN on mice with skin injury, we also interestingly found changes in some genes related to the AMPK signaling pathway, such as adiponectin receptor-binding protein (APPL1), liver kinase B (LKB1), silencing information regulator (SIRT1), mammalian target of rapamycin (mTOR), forkhead transcription factor O1 (FOXO), and peroxisome proliferative receptor $\gamma$ co-activator $\alpha$ (PGC$1 \alpha)$. APPL1 is a functional protein located on chromosome 3 upstream of the gene encoding AMPK and is composed of 709 amino acids. It mediates a variety of cell signaling pathways, regulates the inflammatory response of cells, and has antioxidant and anti-arteriosclerotic effects. ${ }^{75}$ LKB1 is a kinase upstream of AMPK and is mainly localized in the nucleus. It can directly phosphorylate threonine 172 on the $\alpha$ subunit of AMPK to activate AMPK, thereby regulating the energy metabolism of cells. ${ }^{76}$ mTOR is an evolutionarily conserved serine/threonine protein kinase and an integrator of growth factors and nutritional signals. The activation of the mTOR pathway is thought to be closely related to the mechanism of cutaneous melanoma. ${ }^{77}$ In addition, an early study demonstrated UV radiation increased protein expression of mTOR and decreased expression of LKB1 by inhibiting the activation of AMPK. ${ }^{78}$ SIRT1 increases the expression of PGC- $1 \alpha$ through deacetylation, which acts as an important regulator in mitochondrial biosynthesis and can directly regulate the number and function of mitochondria. ${ }^{79}$ Studies proved that UVA-irradiation decreased the activation of the AMPK/ SIRT-1/PGC-1 $\alpha$ pathway in HaCaT cells and HFF-1 cells. ${ }^{80}$ The present study also found the mRNA and protein expression of AMPK, SIRT-1, and PGC- $1 \alpha$ decreased in UVB-induced skin damage. Other research using human dermal fibroblasts and a 3D skin model to evaluate the effect of Aquatide on UV-induced skin aging found that Aquatide upregulated the expression of FOXO1 by activating the expression of SIRT- $1 .{ }^{81}$ In this study, we found that after intraperitoneal injection of NMN to UVB-exposed mice, the mRNA expression levels of APPL1, LKB1, SIRT1, FOXO1, and PGC-1 $\alpha$ in mouse skin and liver significantly increased, while the mRNA expression levels of
mTOR decreased. This indicates that NMN blocks UVBinduced skin damage in mice by regulating the AMPK signaling pathway.

\section{Conclusions}

In summary, our experiment found that NMN intraperitoneal injection had an obvious protective effect on UVBinduced skin damage in mice. The possible mechanisms of this effect are presented in Figure 7. NMN intraperitoneal injection inhibited the activation of the NF- $\mathrm{\kappa B}$ signaling pathway by activating the AMPK signaling pathway. Moreover, the changes of these two pathways by NMN regulated the expression and release of other oxidative and inflammatory indicators, thereby reducing the skin damage caused by UVB irradiation. This study shows that the protective effect of NMN administered via intraperitoneal injection on UVB-induced skin damage in mice is similar to the effect of oral gavage of NMN that we reported previously. This study provides a reference for further research using the form of NMN administration.

\section{Abbreviations}

T-SOD, total superoxide dismutase; CAT, catalase; GSH, glutathione; NADK, NAD Kinase; $\mathrm{H} 2 \mathrm{O} 2$, hydrogen peroxide; TNF- $\alpha$, tumor necrosis factor- $\alpha$; IL-1 $\beta$, interleukin- $1 \beta$; IL-6, interleukin-6; IL-4, and interleukin-4; IL-10, interleukin-10; IкB- $\alpha$, NF-kappa-B inhibitor- $\alpha$; AMPK, AMPactivated protein kinase; SIRT1, silent information regulator 1; PGC-1 $\alpha$, peroxisome proliferator-activated receptor $\gamma$ coactivator- $1 \alpha$; FOXO, forkhead transcription factor O; LKB1, adiponectin receptor binding protein; mTOR, mammalian target of rapamycin; APPL1, adaptor protein containing PH domain, PTB domain and Leucine zipper motif 1.

\section{Data Sharing Statement}

All data generated or analyzed during this study are included in this article. The datasets used and/or analyzed during the current study are available from the corresponding author on reasonable request.

\section{Ethical Statement}

The study was performed according to 2010/63/EU directive and national standard of the people's Republic of China (GB/T 35892-2018) laboratory animal-guidelines for ethical review of animal welfare and institutional rules considering animal experiments. At the same time, the study protocol was approved by the Ethics Committee 
of Chongqing Collaborative Innovation Center for Functional Food (201908001A, Chongqing, China).

\section{Consent for Publication}

Not Applicable. This article does not contain any studies with human participants performed by any of the authors.

\section{Funding}

This research was funded by the Chongqing University Innovation Research Group Project (CXQTP20033), Project of National Center for Schooling Development Programme and Children's Research Institute of Chongqing University of Education (CRIKT202001) and the Research Project of Chongqing University of Education (KY202129C), China.

\section{Disclosure}

The authors declare that they have no conflicts of interest.

\section{References}

1. Bragazzi NL, Sellami M, Salem I, et al. Fasting and its impact on skin anatomy, physiology, and physiopathology: a comprehensive review of the literature. Nutrients. 2019;11(2):249. doi:10.3390/ nu11020249

2. Krutmann J, Bouloc A, Sore G, Bernard BA, Passeron T. The skin aging exposome. $J$ Dermatol Scim. 2017;85(3):152-161. doi:10.1016/j.jdermsci.2016.09.015

3. Oh M, Lee J, Kim YJ, Rhee WJ, Park JH. Exosomes derived from human induced pluripotent stem cells ameliorate the aging of skin fibroblasts. Int $J$ Mol Sci. 2018;19(6):1715. doi:10.3390/ ijms 19061715

4. Battie C, Jitsukawa S, Bernerd F, Del Bino S, Marionnet C, Verschoore M. New insights in photoaging, UVA induced damage and skin types. Exp Dermatol. 2014;23(Suppl 1):7-12. doi:10.1111/ exd. 12388

5. Cho S, Kim HH, Lee MJ, et al. Phosphatidylserine prevents UV-induced decrease of type I procollagen and increase of MMP-1 in dermal fibroblasts and human skin in vivo. J Lipid Res. 2008;49 (6):1235-1245. doi:10.1194/jlr.M700581-JLR200

6. Baumann L. Skin ageing and its treatment. J Pathol. 2007;211 (2):241-251. doi:10.1002/path.2098

7. Akase T, Nagase T, Huang L, et al. Aging-like skin changes induced by ultraviolet irradiation in an animal model of metabolic syndrome. Biol Res Nurs. 2012;14(2):180-187. doi:10.1177/1099800411401013

8. Poddar SK, Sifat AE, Haque S, Nahid NA, Chowdhury S, Mehedi I. Nicotinamide mononucleotide: exploration of diverse therapeutic applications of a potential molecule. Biomolecules. 2019;9(1):34. doi:10.3390/biom9010034

9. Hosseini L, Vafaee MS, Badalzadeh R. Melatonin and nicotinamide mononucleotide attenuate myocardial ischemia/reperfusion injury via modulation of mitochondrial function and hemodynamic parameters in aged rats. J Cardiovasc Pharmacol Ther. 2020;25(3):240-250. doi: $10.1177 / 1074248419882002$

10. Wang X, Hu X, Yang Y, Takata T, Sakurai T. Nicotinamide mononucleotide protects against $\beta$-amyloid oligomer-induced cognitive impairment and neuronal death. Brain Res. 2016;1643:1-9. doi:10.1016/j.brainres.2016.04.060
11. Yoshino J, Mills KF, Yoon MJ, Imai S. Nicotinamide mononucleotide, a key NAD $(+)$ intermediate, treats the pathophysiology of dietand age-induced diabetes in mice. Cell Metab. 2011;14(4):528-536. doi:10.1016/j.cmet.2011.08.014

12. Grolla AA, Miggiano R, Di Marino D, et al. A nicotinamide phosphoribosyltransferase-GAPDH interaction sustains the stress-induced NMN/NAD+ salvage pathway in the nucleus. $J$ Biol Chem. 2020;295(11):3635-3651. doi:10.1074/jbc.RA119.010571

13. Bertoldo MJ, Listijono DR, Ho WJ, et al. NAD+ repletion rescues female fertility during reproductive aging. Cell Rep. 2020;30 (6):1670-1681. doi:10.1016/j.celrep.2020.01.058

14. Tarantini S, Valcarcel-Ares MN, Toth P, et al. Nicotinamide mononucleotide (NMN) supplementation rescues cerebromicrovascular endothelial function and neurovascular coupling responses and improves cognitive function in aged mice. Redox Biol. 2019;24:101192. doi:10.1016/j.redox.2019.101192

15. Yu J, Laybutt DR, Kim LJ, et al. Exercise-induced benefits on glucose handling in a model of diet-induced obesity are reduced by concurrent nicotinamide mononucleotide. Am J Physiol Endocrinol Metab. 2021;321(1):E176-E189. doi:10.1152/ajpendo.00446.2020

16. Zhao C, Li W, Duan H, et al. NAD+ precursors protect corneal endothelial cells from UVB-induced apoptosis. Am J Physiol Cell Physiol. 2020;318(4):C796-C805. doi:10.1152/ajpcell.00445.2019

17. Uddin GM, Youngson NA, Doyle BM, Sinclair DA, Morris MJ. Nicotinamide mononucleotide (NMN) supplementation ameliorates the impact of maternal obesity in mice: comparison with exercise. Sci Rep. 2017;7(1):15063. doi:10.1038/s41598-017-14866-Z

18. Xie X, Yu C, Zhou J, et al. Nicotinamide mononucleotide ameliorates the depression-like behaviors and is associated with attenuating the disruption of mitochondrial bioenergetics in depressed mice. $J$ Affect Disord. 2020;263:166-174. doi:10.1016/j.jad.2019.11.147

19. Iwaniec UT, Turner RT. Intraperitoneal injection of ethanol results in drastic changes in bone metabolism not observed when ethanol is administered by oral gavage. Alcohol Clin Exp Res. 2013;37 (8):1271-1277. doi:10.1111/acer.12105

20. Pugine SM, Brito P, Alba-Loureiro TC, Costa EJ, Curi R, De Melo MP. Effect of indole-3-acetic acid administration by gavage and by subcutaneous injection on rat leukocytes. Cell Biochem Funct. 2007;25(6):723-730. doi:10.1002/cbf.1383

21. Zhou X, Du HH, Ni L, et al. Nicotinamide mononucleotide combined with lactobacillus fermentum TKSN041 reduces the photoaging damage in murine skin by activating AMPK signaling pathway. Front Pharmacol. 2021;12:643089. doi:10.3389/fphar.2021.643089

22. Milton Prabu S, Shagirtha K, Renugadevi J. Quercetin in combination with vitamins ( $\mathrm{C}$ and $\mathrm{E}$ ) improves oxidative stress and renal injury in cadmium intoxicated rats. Eur Rev Med Pharmacol Sci. 2010;14:903-914.

23. Ochiai Y, Kaburagi S, Obayashi K, et al. A new lipophilic pro-vitamin $\mathrm{C}$, tetra-isopalmitoyl ascorbic acid (VC-IP), prevents UV-induced skin pigmentation through its anti-oxidative properties. J Dermatol Sci. 2006;44(1):37-44. doi:10.1016/j.jdermsci.2006.07.001

24. Sealey WM, Gatlin DM 3rd. Dietary vitamin C and vitamin $\mathrm{E}$ interact to influence growth and tissue composition of juvenile hybrid striped bass (Morone chrysops (female) x M. saxatilis (male)) but have limited effects on immune responses. $J$ Nutr. 2002;132(4):748-755. doi:10.1093/jn/132.4.748

25. Bleilevens C, Doorschodt BM, Fechter T, et al. Influence of vitamin $\mathrm{C}$ on antioxidant capacity of in vitro perfused porcine kidneys. Nutrients. 2019;11(8):1774. doi:10.3390/nu11081774

26. Che DN, Xie GH, Cho BO, Shin JY, Kang HJ, Jang SI. Protective effects of grape stem extract against UVB-induced damage in C57BL mice skin. $J$ Photochem Photobiol B Biol. 2017;173:551-559. doi:10.1016/j.jphotobiol.2017.06.042

27. Yi R, Zhang J, Sun P, Qian Y, Zhao X. Protective effects of kuding tea (Ilex kudingcha C. J. Tseng) polyphenols on UVB-induced skin aging in SKH1 hairless mice. Molecules. 2019;24(6):1016. doi:10.3390/molecules 24061016 
28. Cejka C, Ardan T, Sirc J, et al. Hydration and transparency of the rabbit cornea irradiated with UVB-doses of $0.25 \mathrm{~J} / \mathrm{cm} 2$ and $0.5 \mathrm{~J} / \mathrm{cm}$ 2 compared with equivalent UVB radiation exposure reaching the human cornea from sunlight. Curr Eye Res. 2011;36(7):607-613. doi:10.3109/02713683.2011.574332

29. Irie J, Inagaki E, Fujita M, et al. Effect of oral administration of nicotinamide mononucleotide on clinical parameters and nicotinamide metabolite levels in healthy Japanese men. Endocr J. 2020;67 (2):153-160. doi:10.1507/endocrj.EJ19-0313

30. Chagas PM, Fulco B, Sari M, Roehrs JA, Nogueira CW. Bis(phenylimidazoselenazolyl) diselenide elicits antinociceptive effect by modulating myeloperoxidase activity, NOx and NFkB levels in the collagen-induced arthritis mouse model. J Pharm Pharmacol. 2017;69(8):1022-1032. doi:10.1111/jphp.12738

31. Hong S, Lee B, Kim JH, et al. Solanum nigrum linne improves DNCB-induced atopic dermatitis-like skin disease in BALB/c mice. Mol Med Rep. 2020;22:2878-2886.

32. De Oliveira NF, Andia DC, Planello AC, et al. TLR2 and TLR4 gene promoter methylation status during chronic periodontitis. $J$ Clin Periodontol. 2011;38(11):975-983. doi:10.1111/j.1600-051X.2011.01765.x

33. Liu J, Ni J, Li LJ, Leng RX, Pan HF, Ye DQ. Decreased UBASH3A mRNA expression levels in peripheral blood mononuclear cells from patients with systemic lupus erythematosus. Inflammation. 2015;38 (5):1903-1910. doi:10.1007/s10753-015-0170-9

34. Qian Y, Zhang J, Zhou X, et al. Lactobacillus plantarum CQPC11 isolated from Sichuan pickled cabbages antagonizes d-galactoseinduced oxidation and aging in mice. Molecules. 2018;23(11):3026. doi:10.3390/molecules23113026

35. Wang R, Yang Z, Zhang J, Mu J, Zhou X, Zhao X. Liver injury induced by carbon tetrachloride in mice is prevented by the antioxidant capacity of anji white tea polyphenols. Antioxidants (Basel). 2019;8(3):64. doi:10.3390/antiox8030064

36. Gilda JE, Gomes AV. Stain-free total protein staining is a superior loading control to $\beta$-actin for western blots. Anal Biochem. 2013;440 (2):186-188. doi:10.1016/j.ab.2013.05.027

37. Pandey N, Giri S. Melatonin attenuates radiofrequency radiation ( 900 $\mathrm{MHz}$ )-induced oxidative stress, DNA damage and cell cycle arrest in germ cells of male Swiss albino mice. Toxicol Ind Health. 2018;34 (5):315-327. doi:10.1177/0748233718758092

38. Gao X, Luo F, Zhao H, Franco JL. Cloves regulate Na+-K+-ATPase to exert antioxidant effect and inhibit UVB light-induced skin damage in mice. Oxid Med Cell Longev. 2021;2021:5197919. doi: $10.1155 / 2021 / 5197919$

39. Park J, Halliday GM, Surjana D, Damian DL. Nicotinamide prevents ultraviolet radiation-induced cellular energy loss. Photochem Photobiol. 2010;86(4):942-948. doi:10.1111/j.1751-1097.2010.00746.x

40. Mori Y, Aki K, Kuge K, et al. UV B-irradiation enhances the racemization and isomerizaiton of aspartyl residues and production of Ne-carboxymethyl lysine (CML) in keratin of skin. J Chromatogr B Analyt Technol Biomed Life Sci. 2011;879(29):3303-3309. doi:10.1016/j.jchromb.2011.05.010

41. Her Y, Shin BN, Lee YL, et al. Oenanthe javanica extract protects mouse skin from UVB radiation via attenuating collagen disruption and inflammation. Int J Mol Sci. 2019;20(6):1435. doi:10.3390/ijms20061435

42. Wu CL, Qiang L, Han W, Ming M, Viollet B, He YY. Role of AMPK in UVB-induced DNA damage repair and growth control. Oncogene. 2013;32(21):2682-2689. doi:10.1038/onc.2012.279

43. Kauppinen A, Suuronen T, Ojala J, Kaarniranta K, Salminen A. Antagonistic crosstalk between NF- $\kappa$ B and SIRT1 in the regulation of inflammation and metabolic disorders. Cell Signal. 2013;25 (10):1939-1948. doi:10.1016/j.cellsig.2013.06.007

44. Yu KX, Wong CL, Ahmad R, Jantan I. Larvicidal activity, inhibition effect on development, histopathological alteration and morphological aberration induced by seaweed extracts in Aedes aegypti (Diptera: Culicidae). Asian Pac J Trop Med. 2015;8(12):1006-1012. doi:10.1016/j.apjtm.2015.11.011
45. Kligman LH, Murphy GF. Ultraviolet B radiation increases hairless mouse mast cells in a dose-dependent manner and alters distribution of UV-induced mast cell growth factor. Photochem Photobiol. 1996;63(1):123-127. doi:10.1111/j.1751-1097.1996.tb03002.x

46. Zhang JA, Yin Z, Ma LW, et al. The protective effect of baicalin against UVB irradiation induced photoaging: an in vitro and in vivo study. PLoS One. 2014;9(6):e99703. doi:10.1371/journal.pone.0099703

47. Goerz G, Barnstorf W, Winnekendonk G, et al. Influence of UVA and UVB irradiation on hepatic and cutaneous P450 isoenzymes. Arch Dermatol Res. 1996;289(1):46-51. doi:10.1007/s004030050151

48. Widel M, Krzywon A, Gajda K, Skonieczna M, Rzeszowska-Wolny J. Induction of bystander effects by UVA, UVB, and UVC radiation in human fibroblasts and the implication of reactive oxygen species. Free Radic Biol Med. 2014;68:278-287. doi:10.1016/j.freeradbiomed.2013.12.021

49. You Y, Gao Y, Wang H, et al. Subacute toxicity study of nicotinamide mononucleotide via oral administration. Front Pharmacol. 2020;11:604404. doi:10.3389/fphar.2020.604404

50. Okatan DÖ, Kulaber A, Kerimoglu G, Odacı E. Altered morphology and biochemistry of the female rat liver following 900 megahertz electromagnetic field exposure during mid to late adolescence. Biotech Histochem. 2019;94(6):420-428.7. doi:10.1080/10520295.2019.1580767

51. Terra VA, Souza-Neto FP, Pereira RC, et al. Time-dependent reactive species formation and oxidative stress damage in the skin after UVB irradiation. J Photochem Photobiol B. 2012;109:34-41. doi:10.1016/ j.jphotobiol.2012.01.003

52. Wang H, Wei S, Xue X, You Y, Ma Q. Adipose stem cells' antagonism in glycosylation of D-galactose-induced skin aging of nude mice and its skin recovery function. Int J Immunopathol Pharmacol. 2016;29(3):376-385. doi:10.1177/0394632016634348

53. He J, Xu L, Yang L, Wang X. Epigallocatechin gallate is the most effective catechin against antioxidant stress via hydrogen peroxide and radical scavenging activity. Med Sci Monit. 2018;24:8198-8206. doi:10.12659/MSM.911175

54. Arsov S, Graaff R, van Oeveren W, et al. Advanced glycation end-products and skin autofluorescence in end-stage renal disease: a review. Clin Chem Lab Med. 2014;52(1):11-20. doi:10.1515/cclm2012-0832

55. Muramatsu S, Suga Y, Mizuno Y, et al. Differentiation-specific localization of catalase and hydrogen peroxide, and their alterations in rat skin exposed to ultraviolet B rays. J Dermatol Sci. 2005;37 (3):151-158. doi:10.1016/j.jdermsci.2004.11.001

56. Farina M, Aschner M. Glutathione antioxidant system and methylmercury-induced neurotoxicity: an intriguing interplay. Biochim Biophys Acta Gen Subj. 2019;1863(12):129285. doi:10.1016/j.bbagen.2019.01.007

57. Rahman M, Kundu JK, Shin JW, Na HK, Surh YJ, Aggarwal BB. Docosahexaenoic acid inhibits UVB-induced activation of NF- $\kappa \mathrm{B}$ and expression of COX-2 and NOX-4 in HR-1 hairless mouse skin by blocking MSK1 signaling. PLoS One. 2011;6(11):e28065. doi:10.1371/journal.pone.0028065

58. Shats I, Williams JG, Liu J, et al. Bacteria boost mammalian host NAD metabolism by engaging the deamidated biosynthesis pathway. Cell Metab. 2020;31(3):564-579.e7. doi:10.1016/j.cmet.2020.02.001

59. Maurya PK, Prakash S. Decreased activity of Ca++-ATPase and Na +/K+-ATPase during aging in humans. Appl Biochem Biotechnol. 2013;170(1):131-137. doi:10.1007/s12010-013-0172-8

60. Wolf SJ, Estadt SN, Theros J, et al. Ultraviolet light induces increased $\mathrm{T}$ cell activation in lupus-prone mice via type I IFN-dependent inhibition of $\mathrm{T}$ regulatory cells. $J$ Autoimmun. 2019;103:102291. doi:10.1016/j.jaut.2019.06.002

61. Guo G, Shi F, Zhu J, et al. Piperine, a functional food alkaloid, exhibits inhibitory potential against TNBS-induced colitis via the inhibition of $\mathrm{I} \kappa \mathrm{B}-\alpha / \mathrm{NF}-\kappa \mathrm{B}$ and induces tight junction protein (claudin-1, occludin, and ZO-1) signaling pathway in experimental mice. Hum Exp Toxicol. 2020;39(4):477-491. doi:10.1177/ 0960327119892042 
62. Cho BO, Yin HH, Park SH, Byun EB, Ha HY, Jang SI. Antiinflammatory activity of myricetin from Diospyros lotus through suppression of NF-KB and STAT1 activation and Nrf2-mediated HO-1 induction in lipopolysaccharide-stimulated RAW264.7 macrophages. Biosci Biotechnol Biochem. 2016;80(8):1520-1530. doi:10.1080/09168451.2016.1171697

63. Pikarsky E, Porat RM, Stein I, et al. NF-kappaB functions as a tumour promoter in inflammation-associated cancer. Nature. 2004;431(7007):461-466. doi:10.1038/nature02924

64. Da Silva-ferrada E, Torres-Ramos M, Aillet F, et al. Role of mono-

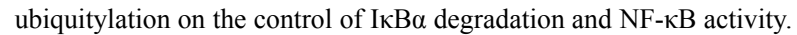
PLoS One. 2011;6(10):e25397. doi:10.1371/journal.pone.0025397

65. Li L, Ngo H, Hwang E, et al. Conditioned medium from human adipose-derived mesenchymal stem cell culture prevents UVB-induced skin aging in human keratinocytes and dermal fibroblasts. Int J Mol Sci. 2019;21(1):49. doi:10.3390/ijms21010049

66. Chaiprasongsuk A, Janjetovic Z, Kim TK, et al. CYP11A1-derived vitamin D3 products protect against UVB-induced inflammation and promote keratinocytes differentiation. Free Radic Biol Med. 2020;155:87-98. doi:10.1016/j.freeradbiomed.2020.05.016

67. Braidy N, Liu Y. NAD+ therapy in age-related degenerative disorders: a benefit/risk analysis. Exp Gerontol. 2020;132:110831. doi:10.1016/j.exger.2020.110831

68. Karin M, Ben-Neriah Y. Phosphorylation meets ubiquitination: the control of NF-[kappa]B activity. Annu Rev Immunol. 2000;18 (1):621-663. doi:10.1146/annurev.immunol.18.1.621

69. Thoma A, Lightfoot AP. NF-kB and inflammatory cytokine signaling: role in skeletal muscle atrophy. Adv Exp Med Biol. 2018;1088:267-279.

70. Zhang M, Wang C, Wu J, et al. The effect and mechanism of KLF7 in the TLR4/NF-kB/IL-6 inflammatory signal pathway of adipocytes. Mediators Inflamm. 2018;2018:1756494. doi:10.1155/2018/1756494

71. Zielinski CE, Mele F, Aschenbrenner D, et al. Pathogen-induced human TH17 cells produce IFN- $\gamma$ or IL-10 and are regulated by IL13. Nature. 2012;484(7395):514-518. doi:10.1038/nature10957

72. Hu Q, Li L, Zou X, Xu L, Yi P. Berberine attenuated proliferation, invasion and migration by targeting the AMPK/HNF4 $\alpha / \mathrm{WNT} 5 \mathrm{~A}$ pathway in gastric carcinoma. Front Pharmacol. 2018;9:1150. doi:10.3389/fphar.2018.01150
73. Salminen A, Kauppinen A, Kaarniranta K. AMP-activated protein kinase inhibits NF- $\mathrm{KB}$ signaling and inflammation: impact on healthspan and lifespan. $J$ Mol Med (Berl). 2011;89(7):667-676. doi:10.1007/s00109-011-0748-0

74. Wang P, Xu TY, Guan YF, et al. Nicotinamide phosphoribosyltransferase protects against ischemic stroke through SIRT1-dependent adenosine monophosphate-activated kinase pathway. Ann Neurol. 2011;69(2):360-374. doi:10.1002/ana.22236

75. He WY, Zhang B, Zhao WC, et al. mTOR activation due to APPL1 deficiency exacerbates hyperalgesia via Rab5/Akt and AMPK signaling pathway in streptozocin-induced diabetic rats. Mol Pain. 2019;15:1744806919880643. doi:10.1177/1744806919880643

76. Zhang YL, Guo H, Zhang CS, et al. AMP as a low-energy charge signal autonomously initiates assembly of AXIN-AMPK-LKB1 complex for AMPK activation. Cell Metab. 2013;18(4):546-555. doi:10.1016/j.cmet.2013.09.005

77. Jia J, Abudu YP, Claude-Taupin A, et al. Galectins control MTOR and AMPK in response to lysosomal damage to induce autophagy. Autophagy. 2019;15:169-171.

78. Cao C, Lu S, Kivlin R, et al. AMP-activated protein kinase contributes to UV- and $\mathrm{H} 2 \mathrm{O} 2$-induced apoptosis in human skin keratinocytes. $J$ Biol Chem. 2008;283(43):28897-28908. doi:10.1074/jbc.M804144200

79. Chandrasekaran K, Anjaneyulu M, Choi J, et al. Role of mitochondria in diabetic peripheral neuropathy: influencing the NAD+dependent SIRT1-PGC-1 $\alpha$-TFAM pathway. Int Rev Neurobiol. 2019;145:177-209.

80. Jing R, Guo K, Zhong Y, et al. Protective effects of fucoidan purified from Undaria pinnatifida against UV-irradiated skin photoaging. Ann Transl Med. 2021;9(14):1185. doi:10.21037/atm-21-3668

81. Lim CJ, Lee YM, Kang SG, et al. Aquatide activation of SIRT1 reduces cellular senescence through a SIRT1-FOXO1-autophagy axis. Biomol Ther (Seoul). 2017;25(5):511-518. doi:10.4062/ biomolther.2017.119
Journal of Inflammation Research

\section{Publish your work in this journal}

The Journal of Inflammation Research is an international, peerreviewed open-access journal that welcomes laboratory and clinical findings on the molecular basis, cell biology and pharmacology of inflammation including original research, reviews, symposium reports, hypothesis formation and commentaries on: acute/chronic inflammation; mediators of inflammation; cellular processes; molecular

\section{Dovepress}

mechanisms; pharmacology and novel anti-inflammatory drugs; clinical conditions involving inflammation. The manuscript management system is completely online and includes a very quick and fair peerreview system. Visit http://www.dovepress.com/testimonials.php to read real quotes from published authors. 